IZA DP No. 1063

Are Refugees Different from Economic Immigrants? Some Empirical Evidence on the Heterogeneity of Immigrant

Groups in the United States

Kalena E. Cortes

March 2004 


\title{
Are Refugees Different from Economic Immigrants? Some Empirical Evidence on the Heterogeneity of Immigrant Groups in the United States
}

\author{
Kalena E. Cortes \\ Princeton University \\ and IZA Bonn
}
Discussion Paper No. 1063
March 2004

\author{
IZA \\ P.O. Box 7240 \\ 53072 Bonn \\ Germany \\ Phone: +49-228-3894-0 \\ Fax: +49-228-3894-180 \\ Email: iza@iza.org
}

\begin{abstract}
Any opinions expressed here are those of the author(s) and not those of the institute. Research disseminated by IZA may include views on policy, but the institute itself takes no institutional policy positions.

The Institute for the Study of Labor (IZA) in Bonn is a local and virtual international research center and a place of communication between science, politics and business. IZA is an independent nonprofit company supported by Deutsche Post World Net. The center is associated with the University of Bonn and offers a stimulating research environment through its research networks, research support, and visitors and doctoral programs. IZA engages in (i) original and internationally competitive research in all fields of labor economics, (ii) development of policy concepts, and (iii) dissemination of research results and concepts to the interested public.
\end{abstract}

IZA Discussion Papers often represent preliminary work and are circulated to encourage discussion. Citation of such a paper should account for its provisional character. A revised version may be available on the IZA website (www.iza.org) or directly from the author. 


\section{ABSTRACT}

\section{Are Refugees Different from Economic Immigrants? Some Empirical Evidence on the Heterogeneity of Immigrant Groups in the United States*}

This paper analyzes how the implicit difference in time horizons between refugees and economic immigrants affects subsequent human capital investments and wage assimilation. The analysis uses the 1980/1990 Integrated Public Use Samples of the Census to study labor market outcomes of immigrants who arrived in the U.S. from 1975 to 1980. I find that in 1980 refugee immigrants in this cohort earned 6 percent less and worked 14 percent fewer hours than economic immigrants. Both had about the same level of English skills. The two immigrant groups had made substantial gains by 1990; however, refugees had made greater gains. In fact, the labor market outcomes of refugee immigrants surpassed those of economic immigrants. In 1990, refugees from the 1975-1980 arrival cohort earned 20 percent more, worked 4 percent more hours, and improved their English skills by 11 percent relative to economic immigrants. The higher rates of human capital accumulation for refugee immigrants contribute to these findings.

JEL Classification: $\quad$ C81, F22, J24, J31

Keywords: refugee and economic immigrants, human capital investment, wage growth

Kalena E. Cortes

Princeton University

261 Wallace Hall

Princeton, NJ 08544-2091

USA

Tel.: +1 6092585514

Fax: +1609258 1039

Email: kcortes@princeton.edu

\footnotetext{
* I would like to thank David E. Card for all his encouragement and most valued advice. Also, I would like to thank Steven Raphael, Ronald D. Lee, Marta Tienda, Clair Brown, and Ken Chay for their comments and support. I also thank Charles C. Udomsaph, Benjamin A. Campbell, Ethan G. Lewis, Elizabeth U. Cascio, Erica M. Field, Galina Hale, Luis Eduardo Miranda-Cruz, Marcelo J. Morreira, anonymous referees of the Review, and the labor seminar participants at UC Berkeley and Princeton University for their comments. Financial support from the National Institute of Child Health and Human Development (NICHHD) Interdisciplinary Grant (PHS Grant No. 1-784556-31066) is gratefully acknowledged. Research results, conclusions, and all errors are naturally my own.
} 


\section{Introduction}

People choose to immigrate to the United States for a variety of reasons and under different circumstances, and consequently, immigrants cannot be treated as a homogenous group of individuals. Immigrants can be separated into at least two distinct groups: refugee immigrants, individuals fleeing persecution in their home country, and economic immigrants, individuals searching for better jobs and economic security. One important characteristic that distinguishes these two immigrant groups is their ability to return to their native country. Refugee immigrants are unable or unwilling to return home for fear or threat of prosecution, and thus, must make a life in the country that gives them refuge. Economic immigrants, on the other hand, are free from this constraint and can return home whenever they so desire. In fact, for many economic immigrants the purpose of their stay is simply to earn money and then return home to buy land, build a house, support immediate and extended family members, and retire in their motherland. A second observable difference between these two immigrant groups is that refugee immigrants are likely to have fewer social contacts with their home country through return visits. In contrast, economic immigrants are able to make trips to see family members, relatives, and friends they left behind.

Given the distinct characteristics of refugee and economic immigrants, a natural question to ask is whether these differences have any economic implications. Lacking the option of emigrating back to their homeland, refugee immigrants have a longer time horizon in the host country, and hence, may be more inclined to invest in country-specific human capital. This may take the form of improving language skills, becoming naturalized citizens, and enrolling in the host nation's educational system. This line of reasoning suggests that refugee immigrants are more likely to assimilate to the earnings growth path of the native-born population. Previous 
research that averages all immigrants may overlook this important distinction (Carliner 1980; Stewart and Hyclak 1984; Borjas 1985, 1995).

The innovation of this paper is to introduce into the analysis the distinction between refugee and economic immigrants. This study analyzes how the implicit difference in time horizons between newly-arrived refugees and newly-arrived economic immigrants affects subsequent human capital investments and wage assimilation. Based on Immigration and Naturalization Service definitions, I develop a schema for distinguishing refugees from economic immigrants. Using data from the 1980 and 1990 U.S. Census Public Use Micro Samples, I then construct a synthetic cohort to compare the accumulation of human capital as well as earnings growth over the decade for refugees and economic immigrants. In addition, I present a detailed statistical comparison of the two groups in order to assess whether the demographic composition in terms of age, gender, and family composition conforms to what one might expect a priori.

This paper has two primary findings. First, refugee immigrants on average have lower annual earnings upon arrival; however, their annual earnings grow faster over time than those of economic immigrants. Second, refugees over time tend to have higher Country-Specific Human Capital (CSHC) investment than economic immigrants.

This paper is organized as follows. Section 2 provides a brief literature review, Section 3 illustrates a conceptual model, and Section 4 discusses the empirical methodology and describes the data. Section 5 provides a detailed comparison of the characteristics of refugees and economic immigrants, Section 6 presents the main results of this study, and lastly, Section 7 concludes. 


\section{Literature Review}

The seminal work by Chiswick (1978) on the earnings assimilation of immigrants has generated much research on the topic of economic adjustment of immigrants in the United States. Chiswick estimates cross-sectional earnings regressions for immigrants and finds that the initial earnings of newly-arrived immigrants were about 17 percent less than native-born workers. However, he goes on to show that the age profiles of earnings are steeper for immigrants than natives. Explaining his findings in terms of human capital theory, Chiswick hypothesizes that at the time of arrival immigrants earn less than natives because of their lack of specific skills such as language proficiency. As they acquire the necessary skills and accumulate country-specific human capital, immigrants experience faster wage growth than native-born workers. Chiswick reports that immigrant earnings surpass native earnings within 15 years after immigration; after 30 years of living in the United States, a typical immigrant earns about 11 percent more than a native-born worker. ${ }^{1}$

Recent research that takes a second look at Chiswick's hypothesis concerning countryspecific human capital has focused specifically on the language acquisition and fluency of immigrants (Carliner 1995; Dustmann and van-Soest 2002; Shields and Price 2001; White and Kaufman 1997). For instance, using panel data from Germany, Dustmann and van Soest (2002) show that language proficiency of immigrants is a far more important predictor of earnings than previous literature has suggested.

Moreover, various studies have found a positive relationship between language skills and immigrant success (Carliner 1996; Chiswick 1986, 1991, 1998; Chiswick and Miler 1996;

\footnotetext{
${ }^{1}$ An important series of subsequent papers by Borjas $(1985,1995)$ re-examines Chiswick's conclusions using a cohort of immigrants observed in 1970 and 1980. Borjas finds that the earnings of the cohort grew at a much slower rate than was predicted by cross-section analyses. In fact, Borjas shows that cross-section regressions overestimate the true rate of growth experienced by immigrants by as much as 20 percent for some immigrant cohorts. As a result, empirical research on immigrant wage growth now examines immigrant cohorts or longitudinal data on immigrants rather than single cross section data.
} 
Funkhouser 1995; Rivera-Batiz 1990; Shields and Price 2001). A study by Chiswick (1998), which uses data from the 1983 Census of Israel, analyzes Hebrew speaking skills and their effect on earnings. He finds that immigrant earnings increase with the usage of Hebrew language. In addition, Rivera-Batiz (1990) looks at the effect of English language proficiency on immigrant wages. His results show that lack of English proficiency is indeed a significant factor that constrains the wages of immigrants.

To date, however, nearly all empirical research have failed to consider the important differences between refugees and economic immigrants. A contributing factor is that data on the different status of immigrants are not readily available. The few empirical studies that do make this distinction find very different outcomes between these two immigrant groups (Khan 1997; Borjas 1987). Khan (1997), using data from the 1976 Survey of Income and Education and the 1980 Census of Population, finds that refugees have a higher probability of investing in schooling than other foreign-born residents. ${ }^{2}$ Borjas (1987) finds that the earnings differentials of migrants can be explained by political and economic conditions in the source countries at the time of immigrating.

There has been, however, a considerable amount of theoretical and some empirical research on return migration (Dustmann 1997, 1999, 2000; Galor and Stark 1990, 1991). Dustmann $(1997,1999,2000)$ compares migrants who intend to remain only temporarily in the host country with migrants who stay permanently, and finds that they exhibit different labor market behaviors. A very strong parallel can be drawn from the labor market behaviors and investment incentives of permanent and temporary migrants to refugee and economic immigrants studied in this paper.

\footnotetext{
${ }^{2}$ Khan analyzes only Cuban and Vietnamese refugees, and her analysis is limited to a single cross-sectional comparison due to the nature of the data.
} 


\section{Conceptual Framework: A Model of Human Capital Investment}

This section presents a simple model of country-specific human capital investment when immigrants have the potential option of returning home. ${ }^{3}$ Assume that immigrants work for two periods and that their utility function is simply equal to their net earnings. Immigrants maximize intertemporal expected utility, given by earnings in the first period plus earnings in the second period multiplied by a discount factor, $\beta$ :

$$
\begin{aligned}
& \operatorname{Max} \\
& \{\theta\}
\end{aligned}
$$

In the first period their net earnings are $Y_{1}\left(w_{H}, H_{0}, \theta\right)$, where $w_{H}$ is the market rate of return on a unit of human capital in the host country $(H), H_{0}$ represents an initial level of human capital, and $\theta$ is a choice variable that represents the proportion of time spent investing in human capital (versus working). In the second period, immigrants either remain in the host country $(H)$ or return to their source country $(S)$ and receive net earnings $Y_{2, j}\left(w_{j}, H_{0}, \theta\right)$, where $j=H$, S. Let $Y_{1}$ and $Y_{2, j}$ have the following functional forms:

$$
\begin{aligned}
& Y_{1}=w_{H} H_{0}(1-\theta) \\
& Y_{2, j}=w_{j}\left[H_{0}+f\left(H_{0}, \theta\right)\right], \quad j=H, S
\end{aligned}
$$

where $f\left(H_{0}, \theta\right)$ is the human capital production function and it is assumed to be strictly concave, $f^{\prime}()>$.0 and $f^{\prime \prime}()<.0 \forall \theta \in(0,1)$.

The initial level of human capital of immigrants is assumed to be only partially transferable to the host country. Acquisition of additional country-specific human capital, such as language skills, gives immigrants the competitive edge needed to succeed in the host labor market. Hence, in the first period immigrants invest some fraction of time $\theta$ in acquiring human

\footnotetext{
${ }^{3}$ This model specification is similar to that presented by Duleep and Regets (1999).
} 
capital. Finally, let $p$ represent the probability of staying in the host country, and (1-p) the probability of emigrating back to the source country in the second period. ${ }^{4}$

Substituting these expressions for earnings into the maximization problem, the optimal choice of human capital investment for immigrant $i, \theta^{*}$, is determined by:

$$
\begin{aligned}
& \operatorname{Max}_{\{\theta\}} w_{H} H_{0}(1-\theta)+\beta p\left[w_{H} H_{0}+w_{H} f\left(H_{0}, \theta\right)\right]+\beta(1-p)\left[w_{S} H_{0}+w_{S} f\left(H_{0}, \theta\right)\right] \\
&
\end{aligned}
$$

The optimal choice of $\theta^{*}$ is determined by the first order condition:

$$
-H_{0}+\beta p \frac{\partial f\left(H_{0}, \theta^{*}\right)}{\partial \theta}+\beta(1-p) \frac{w_{S}}{w_{H}} \frac{\partial f\left(H_{0}, \theta^{*}\right)}{\partial \theta}=0
$$

Recalling that $p$ is the probability of staying in the host country, the effect of $p$ on the optimal choice of human capital investment can derived from the above first order condition:

$$
\frac{d \theta^{*}(p)}{d p}=D \cdot\left[\frac{w_{S}}{w_{H}}-1\right]>0
$$

where $D=\frac{\frac{\partial f\left(H_{0}, \theta^{*}(p)\right)}{\partial \theta}}{\frac{\partial^{2} f\left(H_{0}, \theta^{*}(p)\right)}{\partial \theta^{2}}\left[\frac{w_{S}}{w_{H}}+p\left(1-\frac{w_{S}}{w_{H}}\right)\right]}<0$. Since $w_{S}<w_{H}$ and $0<p<1$, the positivity of this expression follows, noting the strict concavity of the human capital production function.

Equation (6) reveals that the higher the probability of remaining in the host country, the greater the amount of human capital investment immigrants will undertake. This result implies that refugee immigrants will invest more in country-specific human capital than economic immigrants. Such additional investment may take the form of English improvement, becoming a citizen, or enrolling in the educational system of the host nation.

\footnotetext{
${ }^{4}$ For simplicity, return migration is assumed to be exogenously given. A more detailed model presenting this probability as endogenous does not alter the qualitative nature of the results.
} 


\section{Empirical Methodology and Data Description}

To test the implications of the model, the analysis uses the five percent Public Use Samples of the 1980 and 1990 U.S. Censuses. Ideally, we would like a panel of earnings and human capital data for immigrants who are clearly identified as having either refugee or economic immigrant status. Unfortunately, this type of data does not currently exist. However, it is possible to simulate a panel with subsequent decennial censuses if one has information on year of arrival and age.

This study analyzes a fixed cohort of immigrants who entered the United States in the years 1975 through $1980 .^{5}$ From the 1980 Census, I include foreign-born individuals ages 16 to 45 who arrived in the U.S. in 1975-1980. From the 1990 Census, I include foreign-born individuals ages 26 to 55 who arrived in the same period. I focus in particularly on the 19751980 arrival cohort for various reasons. First, the Census did not start collecting the English ability variable until the 1980 Census. Since this variable is key to the analysis, I am primarily interested in variables related to Country-Specific Human Capital (CSHC) in the U.S. Second, the Census does not include educational attainment in the home country prior to immigrating to the U.S. By focusing on the latest immigrant cohort reported in the 1980 Census, education in 1980 is a rough proxy for human capital upon arrival. Third, the 1975-1980 arrival cohort is representative of today's immigrant population in the U.S. If I were to use the most recent arrival cohort from the 1970 Census, the resulting cohort would be more representative of the old immigrant waves, primarily European in composition. Lastly, the 1975-1980 cohort of immigrants allows me to include many other refugee groups not present in the 1970 Census. In

\footnotetext{
${ }^{5}$ More precisely, year of immigration for the 1980 Census is $1975-1980$, whereas in the 1990 Census, year of immigration is 1975-1979. The 1980 arrivals for the 1990 Census are included with the 1981 arrivals and are given a different interval of year of immigration (i.e., 1980-1981). Hence, those immigrants included in the 1980 Census, who entered the U.S. before April 1980, are excluded from the sample I analyze from the 1990 Census.
} 
fact, the main refugee group in the 1970 Census would be Cubans.

To date, most empirical papers do not make any distinction between refugee and economic immigrants. Moreover, the Censuses also do not distinguish between refugee and economic immigrants. This paper identifies refugees by country of origin and year of immigration. ${ }^{6}$ Although they come from very different cultures and social norms, refugees have one very important commonality between them - they are all immigrants that must "make it" in the country that gives them refuge. Immigrants from the following countries are classified as refugees: Afghanistan, Cuba, Soviet Union, Ethiopia, Haiti, Cambodia, Laos, and Vietnam. Individuals from the following countries and regions constitute the economic immigrants: Mexico, Central America, the Caribbean, South America, Northern Europe, Western Europe, Southern Europe, Central Eastern Europe, East Asia, Southeast Asia, the Middle East/Asia Minor, the Philippines, and Northern Africa.

Table 1 describes the refugee and economic immigrant groups and the corresponding samples sizes in the 1980 and 1990 Censuses. Note that all the groups are restricted to having arrived in the U.S. in the years 1975 through 1980. For purposes of comparison, the last column in this table shows the number of legal admits from each country of origin over the 1975-1979 period. ${ }^{7}$ The individual country counts from the 1980 Census are higher than or roughly

\footnotetext{
${ }^{6}$ An excellent source for data on the timing of refugee inflows is Haines (1996). In addition, the INS publishes a yearly volume of immigration statistics, which includes the total number of refugees, asylum seekers, and immigrants from each country admitted during the fiscal year. After compiling the refugee groups for this paper using information from Haines (1996), I then compared them to the INS statistics. The dates and countries correspond very closely.

${ }^{7}$ I use the statistical yearbook from INS data on the number of admits between 1975-1979, divided by 20. The Cuban count is taken from Borjas and Bratsberg (1996) because the statistical yearbook has an apparent typo in the Cuban series. The Borjas series is from the INS microdata files and corresponds very closely to his and my own 1980 Census counts on Cubans.
} 
comparable to the INS counts. Presumably, some of this reflects illegal immigrants who are captured in the census. ${ }^{8}$

\section{Table 1 Insert Here}

Measurement error exists for some of the refugee groups. Since "year of immigration” is coded in intervals in the Census data, some economic immigrants may have been captured as part of refugee waves coming from the same countries. For example, although the refugee wave from a certain country began in 1977, all foreign-born individuals immigrating from that country to the United States in the years 1975 through 1980 are labeled as refugees. The estimates of differences between refugee and economic immigrants are then expected to be downward biased, because the slippage in defining arrival groups will make the refugee groups look more like the economic immigrants. Fortunately, most of the refugee waves started before 1975 and had a constant inflow through at least 1980, and so this bias is likely to be small.

\section{Characteristics of Refugees and Economic Immigrants}

In order to evaluate whether this classification system is picking up meaningful differences, I present some demographic and human capital characteristics by immigrant status. A priori, we would expect that refugee immigrants are closer to a random sample from the source country than economic immigrants. Therefore, we would expect refugees to be more evenly distributed around all ages. On the other hand, we would expect economic immigrants to be disproportionately of working age when they arrive. Figure 1 shows the age distributions of both refugee and economic immigrants by age at the time of arrival for this fixed cohort with year of immigration 1975 through 1980. Consistent with predictions, economic immigrants are

\footnotetext{
${ }^{8}$ The U.S. Censuses include both legal and illegal immigrants, and this concern has been well documented in many other studies (Passel 1986; Warren and Passel 1987; Borjas and Bratsberg, 1996). Also, it is important to note that the INS counts contain only individuals who are admitted legally to the U.S. The INS counts do not contain individuals who entered the U.S. illegally, and therefore, the INS counts will be smaller than the U.S. Census counts.
} 
more likely to come between the ages of 18 and 35 in contrast to refugee immigrants. Interestingly, for economic immigrants we have a bimodal distribution, with the first distribution clustered around very young ages and the second distribution clustered around the working age.

Figure 1 Insert Here

Figures 2, 3, and 4 show the predicted probabilities of school enrollment, ability to speak English, and citizenship by years in the U.S. for refugee and economic immigrants, using pooled 1980 and 1990 Census data. ${ }^{9}$ Looking at Figure 2, we see that refugee immigrants have a higher probability of being enrolled in school than economic immigrants. For instance, the probability of being in school given that a refugee immigrant has resided in the U.S. between 0 to 5 years is 16 percent in contrast to a 9 percent probability for an economic immigrant. These differences are similar for both males and females.

Figure 2 Insert Here

Figure 3 shows the predicted probabilities of low English ability given that a refugee or an economic immigrant has lived in the U.S. between 0 to 5 and 11 to 15 years. We observe that the English ability of both groups improves over time, with refugees experiencing faster rates of improvement. Indeed, although both groups start off with approximately the same level of English ability, within 11 years the probability of low English for refugees decreases to 30 percent whereas for economic immigrants it falls to only 43 percent.

Figure 3 Insert Here

Finally, Figure 4 shows the predicted probabilities of attaining citizenship status conditional on time in the U.S. For the pooled sample we observe that refugee and economic

\footnotetext{
${ }^{9}$ These probabilities were estimated using a probit regression model that controlled for years in the U.S. (interacted with refugee status) and age. The samples include all foreign-born individuals ages 16 to 45 from the 1980 Census and ages 26-55 from the 1990 Census with year of immigration 1975-1980 for 1980 and 1975-1979 for 1990 from the countries listed in Table 1.
} 
immigrants with at least five years of residency in the U.S. have fairly similar low probabilities of becoming a citizen. However, after 11 or more years in the U.S., refugees are much more likely than economic immigrants to have become citizens, 63 percent versus 39 percent, respectively.

\section{Data and Summary}

Figure 4 Insert Here

Table 2 shows several characteristics from the 1980 and 1990 Censuses for this fixed cohort of 1975-1980 immigrant arrivals. Interestingly, the gender composition of each group at time of immigration is similar regardless of refugee status. We might have expected that economic immigrants are more likely to be male, if we assume that men are more likely to come to the U.S. to earn money. The percentage of married individuals is also roughly the same for refugee and economic immigrants. Moreover, both groups appear to have emigrated with about the same number of children and also have about the same number of children born in the U.S. Similarly, the majority of refugee and economic immigrants live in the west region of the U.S. in both Census years.

\section{Table 2 Insert Here}

However, while the above family characteristics of refugee and economic immigrants are similar, their educational levels are not. From Table 2, we observe that economic immigrants were more concentrated in the lower levels of education than refugees in 1980. Furthermore, the education distribution for economic immigrants shows little or no improvement over time, whereas for refugees there is some evidence of rising educational attainment. Finally, although both groups had similar levels of low English ability and citizenship status in 1980, refugees show greater improvement by 1990, as illustrated by the predicted probabilities shown in Figures 3 and 4. 
Table 3 shows data on the annual earnings, average weekly earnings, and average hourly earnings of refugee and economic immigrants in 1980 and 1990. Looking at the first column of Table 3, we observe that in 1980 the typical refugee immigrant earned 6 percent less than an economic immigrant. By 1990, however, the annual earnings of refugees were 20 percent above those of economic immigrants. The relative gain of refugee immigrants from 1980 to 1990 (shown in bold) is 26 percent. The same pattern is observed if we separate the sample by gender. In 1980 we observe that a typical male refugee earned 8 percent less than a male economic immigrant. By 1990, the annual earnings of male refugees were 20 percent higher than those of male economic immigrants, resulting in a relative gain of 28 percent from 1980 to 1990. Similarly, the relative gain of female refugees is 21 percent over this same period. It is worth noting that, from the comparisons of means given in Table 3, we can infer that the relative gain of refugees in annual earnings is mainly coming from a relative increase in the total annual hours worked. The relative gain in average hourly earnings is only 8 percent or about one third of the total gain in annual earnings.

Table 3 Insert Here

\section{Empirical Results}

\subsection{Model Specification and Regression Analysis}

In this section, a more formal analysis of the determinants of earnings growth is presented in order to further examine and explain the reasons why refugees have outperformed economic immigrants. The results are generally similar to those based on the simple comparisons of means given in Table 3. That is, the relatively faster growth of annual earnings of refugees is mainly attributed to a relative increase in annual hours worked. 
A series of alternative model specifications of the human capital function was estimated of the form:

$$
\begin{gathered}
\operatorname{Ln}(\text { annearn })_{i, t}=\alpha_{0}+\alpha_{1} D^{1990}+\alpha_{2} D^{\text {Refugee }}+\alpha_{3} D^{1990} D^{\text {Refugee }}+X_{i, t} \gamma+ \\
\text { LowEng }_{i, t} \beta_{t}+\text { Educ }_{i, t} \theta_{t}+\mu_{i, t}
\end{gathered}
$$

where $\operatorname{Ln}(\text { annearn })_{i, t}$ is $\log$ annual wage and salary earnings, $D^{1990}$ is a dummy variable indicating the 1990 census year, $D^{\text {Refugee }}$ is a dummy variable indicating a refugee immigrant, and $D^{1990} D^{\text {Refugee }}$ is an interaction of refugee status and the 1990 Census dummy. The vector $X_{i, t}$ is a set of control variables (i.e., a quartic in age, region indicators, and marital status indicator). LowEng $_{i, t}$ is a vector of country-specific human capital (i.e., low English ability and low English ability in 1990). Educ $c_{i, t}$ is a vector of educational attainment variables (i.e., less than high school (kindergarten, $1^{\text {st }}-4^{\text {th }}$ grade, $5^{\text {th }}-8^{\text {th }}$ grade, $9^{\text {th }}$ grade, $10^{\text {th }}$ grade, $11^{\text {th }}$ grade); high school $\left(12^{\text {th }}\right.$ grade); some college (1 to 3 years of college); college graduate (4 plus years of college); and the interactions of these school variables with the 1990 census dummy). Lastly, $\mu_{i t}$ is an error term.

The regression specification yields several results of interest: The coefficient $\alpha_{1}$ gives the growth in earnings of economic immigrants from 1980 to 1990, the sum of the coefficients $\left(\alpha_{1}+\alpha_{3}\right)$ gives the growth in earnings of refugee immigrants from 1980 to 1990 , the coefficient $\alpha_{3}$ gives the earnings growth of refugee immigrants relative to economic immigrants from 1980 to 1990, and lastly the sum of the coefficients $\left(\alpha_{2}+\alpha_{3}\right)$ gives the level of earnings of refugee immigrants relative to economic immigrants in 1990.

Table 4 reports male and female log annual earning regressions results for several model specifications. Model 1 estimates the basic model without controls, Model 2 estimates the basic model with the standard set of controls (i.e., a quartic in age, region indicators, and marital status indicator), Model 3 includes controls for low English, and Model 4 includes controls for low 
English as well as educational attainment. The regression results of Model 1 show that the annual earnings of male and female economic immigrants grew by 52 and 55 percent over the decade, respectively (coefficient $\alpha_{1}$ ). For refugees, annual earnings growth was much higher 80 percent for males and 76 percent for females (the sum of coefficients $\alpha_{1}+\alpha_{3}$ ). Even with the inclusion of all the control variables, annual earnings of refugees still significantly outperformed those of economic immigrants. From the regression results of Model 4, we observe that the annual earnings of both male and female refugees grew by 29 percent, still much higher than the 9 and 14 percent growth, respectively, for male and female economic immigrants.

Table 4 Insert Here

\section{How Did Refugees Do Compared to Economic Immigrants?}

Regardless of the regression specification, both male and female refugees initially start off at a lower earnings level than economic immigrants. Looking at Model 4 with the full set of controls, we observe that male refugees earned 17 percent less than male economic immigrants in 1980, while female refugees earned 1 percent less than female economic immigrants in 1980. However, by the next Census, both male and female refugees had caught up and in fact surpassed the earnings levels of economic immigrants.

From the model specification without any controls, the estimates in column 1 of Table 4 show that a typical male refugee in 1990 earned about 20 percent more than an male economic immigrant. Even after the inclusion of the standard controls in Model 2, a typical male refugee still earned about 21 percent more than a comparable male economic immigrant in 1990. Although somewhat lower after the inclusion of human capital variables, the earnings level of male refugees in 1990 relative to that of male economic immigrants is still substantially higher. After controlling for English ability and educational attainment, we observe from Models 3 and 4 
that refugee males in 1990 earned about 14 and 3 percent more, respectively; than economic immigrant males.

Also, note that English ability has the expected sign on annual earnings. From Table 4, the regression results for Model 3 reveal that a male immigrant with low English in 1980 earned about 31 percent less than a male immigrant with higher English skills. In 1990, the penalty for low English grew to 48 percent. Looking at Model 4, we observe that this penalty decreases to 22 percent after controlling for educational attainment. Nevertheless, it remains large.

There is indeed higher returns to education for immigrants in 1990. For instance, looking at Model 4 of Table 4, a male immigrant with a college degree in 1980 earned about 5 percent more than a male immigrant with less than a high school degree. In 1990, a male immigrant with a college degree earned about 11 percent more compared to an immigrant male with less than a high school degree. ${ }^{10}$

The same general results are observed for the female regressions. Regardless of model specification, Table 4 shows refugee females having higher levels of earnings than economic immigrant females. Looking at Model 4 with the full set of controls, we observe that refugee females earned about 15 percent more than economic immigrant females in 1990.

As noted earlier, Table 3 reveals that total annual hours worked was a major contributor to the growth of annual earnings for both male and female refugee immigrants. Since annual earnings is the product of hourly earnings and annual hours, the growth in annual earnings can be decomposed into growth in the hourly wage and growth in annual hours. Tables 5 and 6 present the regression models for these two dependent variables. The main finding from these tables is

\footnotetext{
${ }^{10}$ These returns to education were attain by taking the coefficients from Model 4 and converting them into the returns to one additional year of schooling. The omitted group that college graduates (i.e., 18 years of education) is compared to is immigrants with less than high school (i.e., 11 years of education), the 5 and 11 percent were calculated as $0.34 /(18-11)$ and $0.76 /(18-11)$, respectively.
} 
that the relatively faster growth of annual earnings for refugees is primarily due to an increase in annual hours worked - about two-thirds of the growth in annual earnings is attributable to the increase in annual hours worked, while one-third is attributable to hourly earnings growth. These results are generally similar for both males and females.

Table 5 and 6 Insert Here

The female regression results are interesting in light of the study by Baker and Benjamin (1997), who find that married immigrant females generally work more hours at time of arrival while their husbands invest in their human capital. However, they also find that immigrant wives do invest in their own human capital but much later after migration. They explain their results in terms of the "family investment model," that is, immigrant wives take on dead-end jobs to finance their husbands' human capital investments in the first few years after migration. Two important distinctions between our studies are warranted. Baker and Benjamin specifically analyze married immigrant females, and the Canadian Censuses are conducted every five years. In contrast, my study includes married and non-married female immigrants, and more importantly, the U.S. Censuses are conducted every ten years. Another possibility is that the family investment model simply cannot be generalized to U.S. immigrants as suggested by a recent paper by Blau et al. (2003). Using the 1980 and 1990 U.S. Censuses, they replicate the analysis by Baker and Benjamin and find that the family investment model does not hold for married immigrants. In fact, the results by Blau et al. support the findings in this study.

\subsection{Robustness Tests: Illusion or Reality}

This section presents two robustness tests in order to probe the refugee effect results of Section 6.1. The first robustness test takes a simple approach - it examines the earnings growth 
rates of several refugee and economic immigrant groups separated by country/region of origin. The second robustness test takes into account the large fraction of Asians in the refugee category.

The first robustness test assesses the validity of the assumption made in the previous section regarding the sufficiency of separating immigrants into just two categories, refugee and economic. To test this, I separate the refugee and economic immigrant samples by country/region of origin, and then analyze the individual earnings growth coefficients for each group. Table 7 shows the 1980-90 earnings growth for each group, and we observe that refugee groups on average have higher earnings growth. Figures 5 and 6 illustrate the data shown in Table 7 by plotting the earning growth rate densities corresponding to these groups. These two densities are constructed by smoothing the histograms of the earnings growth rates of refugee groups versus economic immigrant groups. For both the male and female samples, we observe two overlapping distributions for refugee and economic immigrants groups. As previously noted in Table 7, a larger fraction of refugee groups have high earnings growth. The distributions for both refugee male and females are skewed to the left, while the distribution for economic immigrant males and females are skewed to the right. These results are consistent with the findings in the previous section.

Table 7, Figure 5, and Figure 6 Insert Here

The second robustness test is conducted in order to investigate whether the difference between refugees and economic immigrants is due solely to the large number of Asian (predominantly Vietnamese) refugees. ${ }^{11}$ This is important since it has been argued that Asian immigrants are more successful in the U.S. than other immigrant groups. To begin the analysis, consider the following decomposition in which the difference in mean outcomes between refugee

\footnotetext{
${ }^{11}$ As can been seen in Table 1, Vietnamese are by far the largest group in the refugee sample.
} 
and economic immigrants is in terms of four groups of interest: Asian refugees, non-Asian refugees, Asian economic immigrants, and non-Asian economic immigrants,

$$
y^{R}-y^{E}=s_{R}\left(y^{A, R}-y^{A, E}\right)+\left(1-s_{R}\right)\left(y^{N A, R}-y^{N A, E}\right)+\left(y^{A, E}-y^{N A, E}\right)\left(s_{R}-s_{E}\right)
$$

where $y^{R}$ and $y^{E}$ are the mean outcomes for refugee and economic immigrants, respectively; $s_{R}$ is the fraction of refugees who are Asian; $\left(1-s_{R}\right)$ is the fraction of refugees who are non-Asian; $s_{E}$ is the fraction of economic immigrants who are Asian; $\left(1-s_{E}\right)$ is the fraction of economic immigrants who are non-Asian; $y^{A, R}$ is the mean earnings of Asian refugees; $y^{N A, R}$ is the mean earnings of non-Asian refugees; $y^{A, E}$ is the mean earnings of Asian economic immigrants; and lastly, $y^{N A, E}$ is the mean earnings of non-Asian economic immigrants. ${ }^{12}$

Recall that the left hand side of equation (8), $y^{R}-y^{E}$, is the estimated coefficient $\alpha_{3}$, which gave the earnings growth of refugees relative to economic immigrants from 1980 to 1990 . Equation (8) shows that the estimated coefficient $\alpha_{3}$ is composed of three terms: the first term is the difference in mean earnings between Asian refugees and Asian economic immigrants weighted by the fraction of refugees who are Asian, the second term is the difference in mean earnings between non-Asian refugees and non-Asian economic immigrants weighted by the fraction of refugees who are non-Asian, and lastly, the third term is the difference in mean earnings between Asian economic immigrants and non-Asian economic immigrants weighted by the difference of the fraction of refugees who are Asian and the fraction of economic immigrants who are Asian. In other words, this estimated coefficient is composed of an Asian refugee term, a non-Asian refugee term, and an Asian effect term,

\footnotetext{
${ }^{12}$ Appendix A.1 shows the derivation of this algebraic expression.
} 


$$
\underbrace{y^{R}-y^{E}}_{\alpha_{3}}=s_{R} \underbrace{\left(y^{A, R}-y^{A, E}\right)}_{\text {Asian Refugee Term }}+\left(1-S_{R}\right) \underbrace{\left(y^{N A, R}-y^{N A, E}\right)}_{\text {Non-Asian Refugee Term }}+\underbrace{\left(y^{A, E}-y^{N A, E}\right)\left(s_{R}-s_{E}\right)}_{\text {"Asian Effect Term" }}
$$

$$
\begin{gathered}
\text { "Refugee Effect Term" } \\
\Leftrightarrow \quad \alpha_{3}=s_{R} \alpha_{3}{ }^{A}+\left(1-s_{R}\right) \alpha_{3}{ }^{N}+\left(y^{A, E}-y^{N A, E}\right)\left(s_{R}-s_{E}\right)
\end{gathered}
$$

where $\alpha_{3}{ }^{A}$ is the earnings growth of Asian refugees relative to Asian economic immigrants from 1980 to 1990 and $\alpha_{3}{ }^{N}$ is the earnings growth of non-Asian refugees relative to non-Asian economic immigrants from 1980 to 1990.

Therefore, to test whether the difference between refugees and economic immigrants is due solely to the large number of Asians, I calculate the contributions (in percent) of the Asian refugee term and the Asian effect term to the coefficient $\alpha_{3}$. If there is a refugee effect, then the contributions of the Asian refugee term and the Asian term to the coefficient $\alpha_{3}$ will be small relative to the contribution of the non-Asian refugee term. Table 8 presents the percentage breakdown of the coefficient $\alpha_{3}{ }^{13}$

\section{Table 8 Insert Here}

From Table 8, we see that the overall contribution of the Asian refugee term and the Asian effect term is a relatively small component of the estimated coefficient $\alpha_{3}$. In fact, the non-Asian refugee term is the component that is driving the growth in the estimated coefficient $\alpha_{3}$. Regardless of the regression specification, we observe that the non-Asian refugee term is the main contributor to the estimated coefficient $\alpha_{3}$ for both male and female regressions. In fact, the Asian refugee and Asian effect terms are decreasing the overall magnitude of this coefficient for females.

\footnotetext{
${ }^{13}$ For the exact model specification used, refer to Appendix A.2.
} 


\subsection{The Effects of Improving English Fluency}

From the results in Section 6, we observe that immigrants with low English ability earn less. We would expect, however, that from one census year to the next there would be some improvement in English skills for both immigrant groups. From the theoretical framework presented in Section 3, we infer that refugee immigrants would invest more in country-specific human capital, such as English language skills, due to their higher probability of remaining in the country.

Table 9 reports the means of low English for the two immigrants groups and their changes over the period 1980-1990. As predicted, we observe that refugees experience a greater decline in low English ability relative to economic immigrants. Specifically, low English ability decreases by 24 percent for refugee males, but only 15 percent for economic immigrant males. Similarly, low English ability decreases by 22 percent for refugee females, but only 12 percent for economic immigrant females. These declines translate into a relative gain of 9 and 10 percent, respectively, for refugee males and females.

\section{Table 9 Insert Here}

Given the above findings reported in Table 9, a natural follow-up question to ask is: What is the monetary value of English improvement? For this analysis, I decompose the dependent variables in order to determine the effect of improved English fluency on annual earnings, average hourly earnings, and annual hours.

Table 10 Insert Here

Table 10 reports the percent contribution to annual earnings, average hourly earnings, and annual hours growth attributable to improving English skills from 1980 to 1990 . The greater improvement in English skills translates into greater gains in earnings for refugees. We observe that the 24 and 22 percent declines in low English for male and female refugees account for 7 
and 5 percent gains in earnings, respectively. ${ }^{14}$ For male and female economic immigrants, on the other hand, the lesser 15 and 12 percent declines in low English account for 6 and 4 percent gains in earnings, respectively. Looking at the effect of English improvement on average hourly earnings, we observe the same pattern. For both male and female refugees, it accounts for a 4 percent gain in average hourly earnings, respectively. In contrast, for economic immigrant males and females, it accounts for a gain of 4 and 3 percent in average hourly earnings, respectively. Similarly, improvement in English skills translates into 3 percent more annual hours worked for male refugees, but only 2 percent more annual hours worked for male economic immigrants.

\section{Conclusion}

This paper analyzes how the implicit difference in the time horizons of immigrants affects their subsequent human capital investments and wage assimilations. In this paper, I identify refugee and non-refugee groups who entered the United States in the years 1975 through 1980. Based on Immigration and Naturalization Service (INS) definitions, I develop a schema for distinguishing refugees from economic immigrants. The major refugee waves analyzed are from Afghanistan, Cuba, the Soviet Union, Ethiopia, Haiti, Cambodia, Laos, and Vietnam. Nonrefugees which I classify as economic immigrants are from Mexico, Central America, the Caribbean, South America, Northern Europe, Western Europe, Southern Europe, Central Eastern Europe, East Asia, Southeast Asia, the Middle East/Asia Minor, the Philippines, and Northern

\footnotetext{
${ }^{14}$ This is the standard Oaxaca decomposition (Oaxaca 1973) where two reduced-form models are estimated and the earnings differential between refugee and economic immigrants is decomposed into investment in English skills and residual effects. Equivalently, to get the investment term, one can simple take the sum of the low English coefficients $\left(\beta_{0}+\beta_{1}\right)$ from the pooled Model 4 specification and then multiply this sum by the mean difference in low English (observed in Table 9). Lastly, to get the percent contribution to log annual earnings, divide by the mean difference in log annual earnings (observed in Table 3). For instance, the 7 percent contribution to earnings from investing in English skills for male refugees is calculated as follows:$$
\frac{\left(\begin{array}{c}
\beta \\
\beta_{0}+\beta_{1}
\end{array}\right) \cdot \Delta L E^{R}}{\left(\begin{array}{c}
\bar{w}^{R}-\bar{w}^{R} \\
90
\end{array}\right)}=\frac{(-0.2153+-0.0066) \cdot(-0.24)}{(0.80)}=0.07 \text {. }
$$ 
Africa. The study uses the 1980 and 1990 five percent Public Use Samples, which allows for the analysis of a synthetic panel of refugee and economic immigrants that entered the US in the years 1975 through 1980 .

I find that refugee immigrants in 1980 earned 6 percent less and worked 14 percent fewer hours than economic immigrants. Both immigrant groups had about the same level of English skills. By 1990, the two groups had made substantial gains; however, refugee immigrants had made greater gains. Refugees in 1990 earned 20 percent more, worked 4 percent more hours, and improved their English skills by 11 percent more than economic immigrants. The relative gain of refugee immigrants is 26 percent in annual earnings and 10 percent in the improvement of English skills. In addition, from the regression results, I observe that about two-thirds of the faster growth in annual earnings of refugees is attributable to faster growth in annual hours and about one-third is attributable to faster growth in hourly wages. The higher rates of human capital accumulation for refugee immigrants contribute to these findings. English improvement accounts for a 7 and 5 percent gain in earnings for refugee males and females, respectively; whereas for economic immigrant males and females, English improvement accounts for a 6 and 4 percent gain in earnings, respectively.

This study demonstrates how the implicit difference in time horizons of immigrants does, in fact, have a significant effect on their labor market performance. The striking comparisons between refugee and economic immigrants are not attributable to any single country of origin or ethnic group. 


\section{References}

Baker, M. and D. Benjamin, “The Role of the Family in Immigrant's Labor Market Activity: An Evaluation of Alternative Explanations,” American Economic Review 87:4 (1997), 705-727.

Blau, F., L. Kahn, J. Moriarty, and A. Souza, “The Role of the Family in Immigrant's LaborMarket Activity: An Evaluation of Alternative Explanations: Comment," American Economic Review 93:1 (2003), 429-447.

Borjas, G., “Assimilation, Changes in Cohort Quality, and the Earnings of Immigrants,” Journal of Labor Economics 3:4 (1985), 463-489.

Borjas, G., "Self-selection and the Earnings of Immigrants," American Economic Review 77:4 (1987), 531-553.

Borjas, G., "Assimilation and Changes in Cohort Quality Revisited: What Happened to Immigration Earnings in the 1980s?,” Journal of Labor Economics 13:2 (1995), 201-245.

Borjas, G. and Bernt Bratsberg, "Who Leaves? The Outmigration of the Foreign-Born,” Review of Economics and Statistics 78:1 (1996), 165-176.

Carliner, G., "Wages, Earnings, and Hours of First, Second and Third Generation American Males,” Economic Inquiry 18:1 (1980), 87-102.

Carliner, G., "The Language Ability of U.S. Immigrants: Assimilation and Cohort Effects," National Bureau of Economic Research Working Paper No. 5222 (1995).

Carliner, G., “The Wages and Language Skills of U.S. Immigrants," National Bureau of Economic Research Working Paper No. 5763 (1996).

Chiswick, B., “The Effect of Americanization on the Earnings of Foreign-Born Men,” Journal of Political Economy 86:5 (1978), 897-921.

Chiswick, B., "Mexican Immigrants: The Economic Dimension," Annals of the American Academy of Political and Social Science 487 (1986), 92-101.

Chiswick, B., “Speaking, Reading, and Earnings Among Low-Skilled Immigrants,” Journal of Labor Economics 9:2 (1991), 149-70.

Chiswick, B., "Hebrew Language Usage: Determinants and Effects on Earnings Among Immigrant in Israel,” Journal of Population Economics 11:2 (1998), 253-271.

Chiswick, B. and P. Miller, "Language and Earnings Among Immigrants in Canada: A Survey," in Duleep, H. O., and P.V. Wunnava eds. Immigrants and Immigration Policy: Individual Skills, Family Ties, and Group Identities, Contemporary Studies in Economics and Financial Analysis, Vol. 79. Greenwich, Conn. and London: JAI Press (1996), 39-56. 
Duleep, H. O. and M. C. Regets, "Immigrants and Human-Capital Investment," American Economic Review 89:2 (1999), 186-91.

Dustmann, C., "Differences in the Labor Market Behavior Between Temporary and Permanent Migrant Women,” Labour Economics 4 (1997), 29-46.

Dustmann, C., “Temporary Migration, Human Capital, and Language Fluency of Migrants,” Scandinavian Journal of Economics 101:2 (1999), 297-314.

Dustmann, C., “Temporary Migration and Economic Assimilation,” Swedish Economic Policy Review 7:2 (2000), 213-244.

Dustmann, C. and A. van-Soest, "Language and the Earnings of Immigrants," Industrial and Labor Relations Review 55:3 (2002), 473-492.

Funkhouser, E., "How Much of Immigrant Wage Assimilation is Related to English Language Acquisition?” University of California, Santa Barbara mimeo (1995).

Galor, O. and O. Stark, "Migrant's Savings, the Probability of Return Migration, and Migrant's Performance,” International Economic Review 31:2 (1990), 463-467.

Galor, O. and O. Stark, “The Probability of Return Migration, Migrant's Work Effort, and Migrant's Performance,” Journal of Development Economics 35:2 (1991), 399-405.

Haines, D., Refugees in America in the 1990s: A Reference Handbook, Westport, Connecticut: Greenwood Press (1996).

Khan, A., "Post-Migration Investment in Education by Immigrants in the United States," Quarterly Review of Economics and Finance 37 (1997), 285-313.

Oaxaca, R., "Male-Female Wage Differentials in Urban Labor Markets,” International Economic Review 14:3 (1973), 693-709.

Passel, J., "Undocumented Immigrants," Annals of the American Academy of Political and Social Science 487 (1986), 181-200.

Rivera-Batiz, F., "English Language Proficiency and the Economic Progress of Immigrants," Economic Letters 34:3 (1990), 295-300.

Shields, M. and W. Price, "Language Fluency and Immigrant Employment Prospects: Evidence from Britain’s Ethnic Minorities,” Applied Economics Letters 8:11 (2001), 741-745.

Stewart, J. and T. Hyclak, "An Analysis of the Earnings Profiles of Immigrants," Review of Economics and Statistics 66:2 (1984), 292-96. 
United States Bureau of the Census, Public Use Samples of Basic Records from the 1980 Census: Description and Technical Documentation. Washington D.C.: Government Printing Office (1983).

United States Bureau of the Census, Census of Population and Housing, 1990: Public Use Microdata Samples, Technical Documentation. Washington D.C.: Government Printing Office (1993).

United States and Naturalization Service, Statistical Yearbook of the Immigration and Naturalization Service. Washington D.C.: Government Printing Office (various volumes 19781996).

Warren, R. and J. Passel, "A Count of the Uncountable: Estimates of Undocumented Aliens Counted in the 1980 United State Census,” Demography 24:3 (1987), 375-393.

White, M. and G. Kaufman, "Language Usage, Social Capital, and School Completion Among Immigrants and Native-Born Ethnic Groups,” Social Science Quarterly 78:2 (1997), 385-98. 


\section{FiguRE 1.-AgE DisTRIBUTIONS OF ENTERING REFUGEE AND ECONOMIC}

IMMIGRANTS, 1975-1980 (AGE AT TIME OF ARRIVAL)

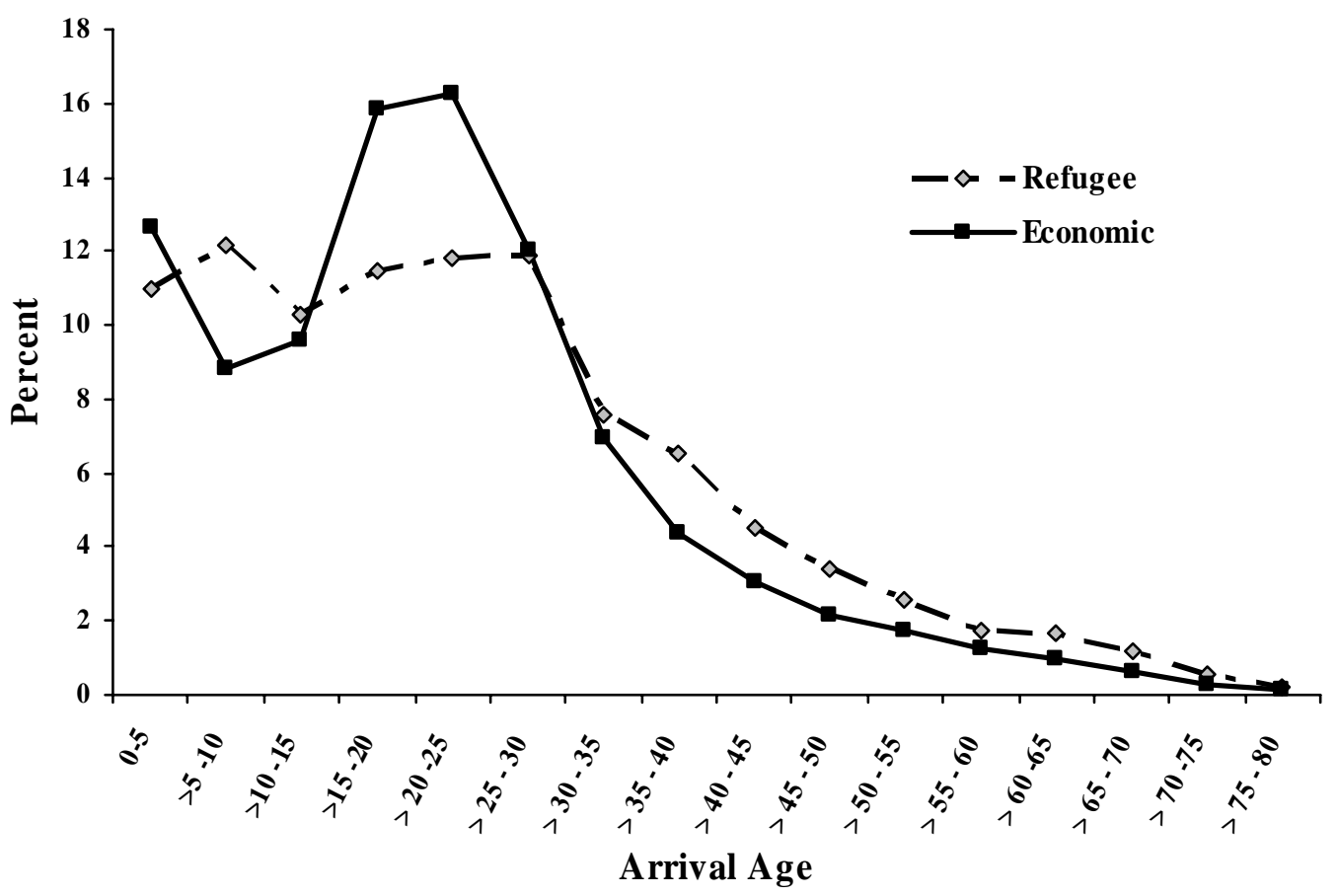

Source: Census Public Use Micro Samples (PUMS) 1980 tabulations by author 
Figure 2.-School Enrollment Profiles for the Pooled SAMPle

$\leadsto$ Refugee $\rightarrow$ Economic

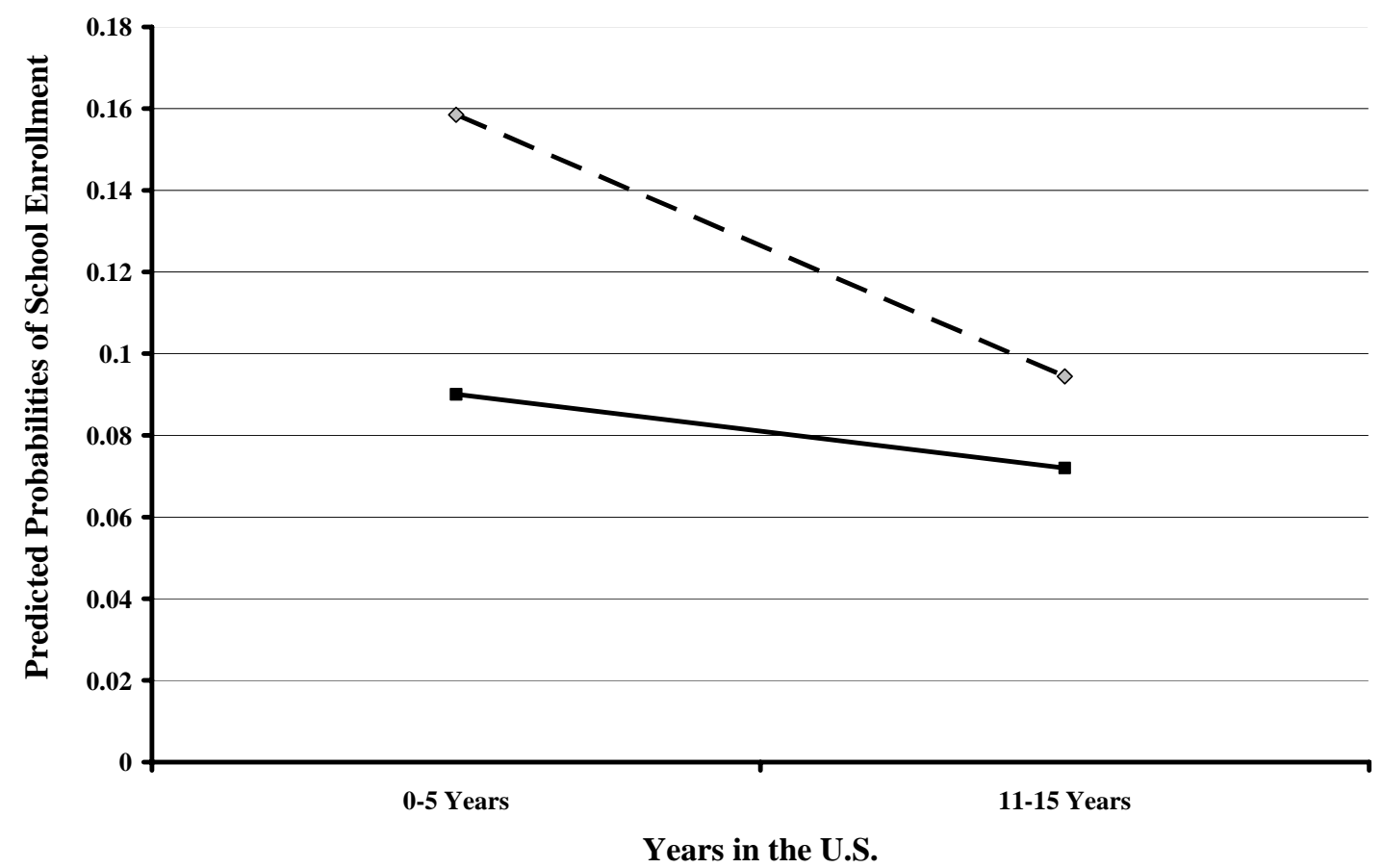

Notes: Sample selection of foreign-born individuals ages 16 to 45 for 1980 and ages 26 to 55 for 1990 . Year of immigration 1975-1980 for 1980 and 1975-1979 for 1990 Censuses.

Source: Census Public Use Micro Samples (PUMS) 1980 and 1990, tabulations by author. 
Figure 3.-Low English Profiles for the Pooled SAMPle

$-\diamond$ Refugee $\rightarrow$ Economic

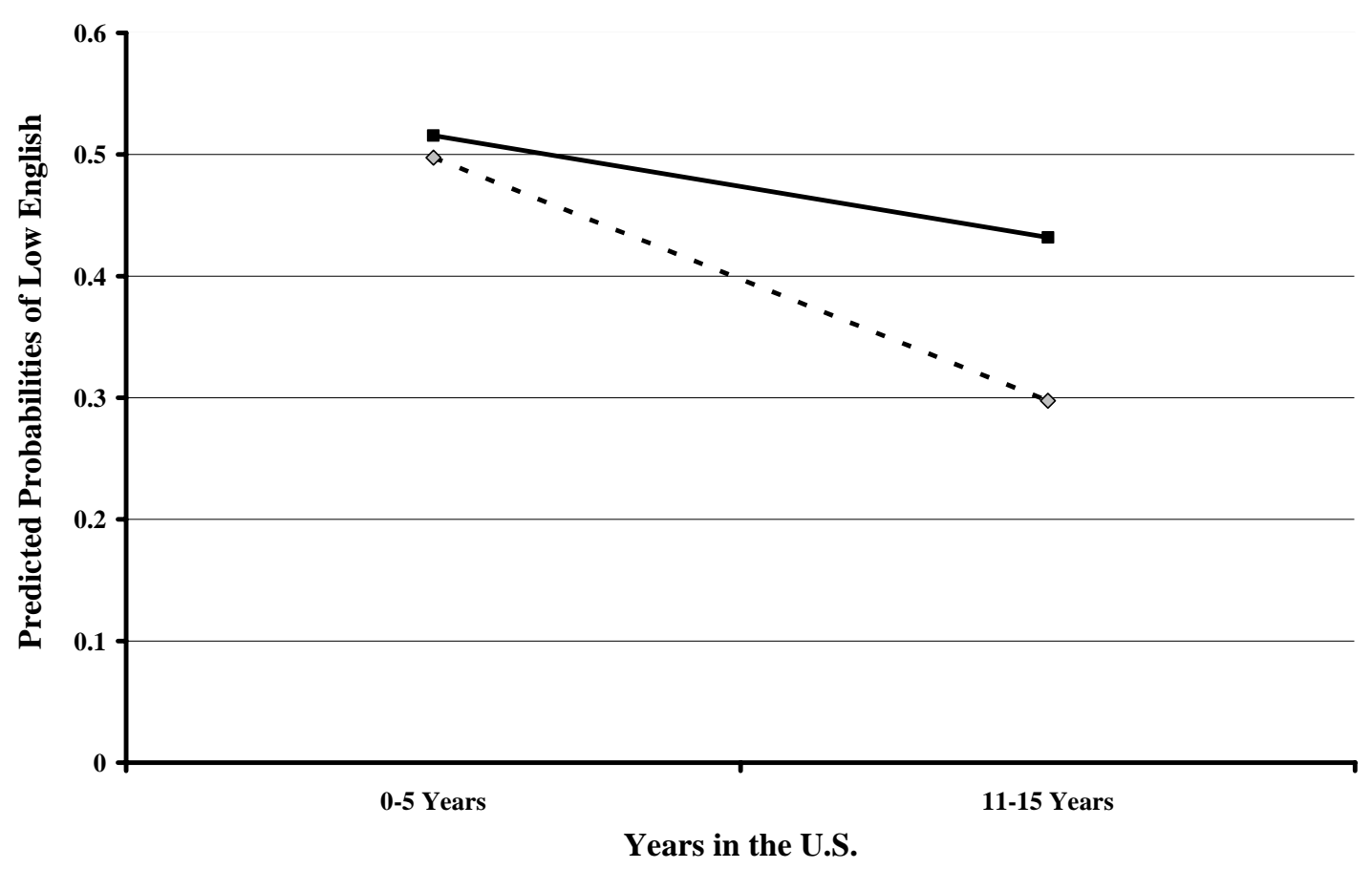

Notes: Sample selection of foreign-born individuals ages 16 to 45 for 1980 and ages 26 to 55 for 1990 . Year of immigration 1975-1980 for 1980 and 1975-1979 for 1990 Censuses.

Source: Census Public Use Micro Samples (PUMS) 1980 and 1990, tabulations by author. 


\section{Figure 4.-Citizenship Status Profiles for the Pooled Sample}

\section{$-\diamond$ Refugee $\rightarrow-$ Economic}

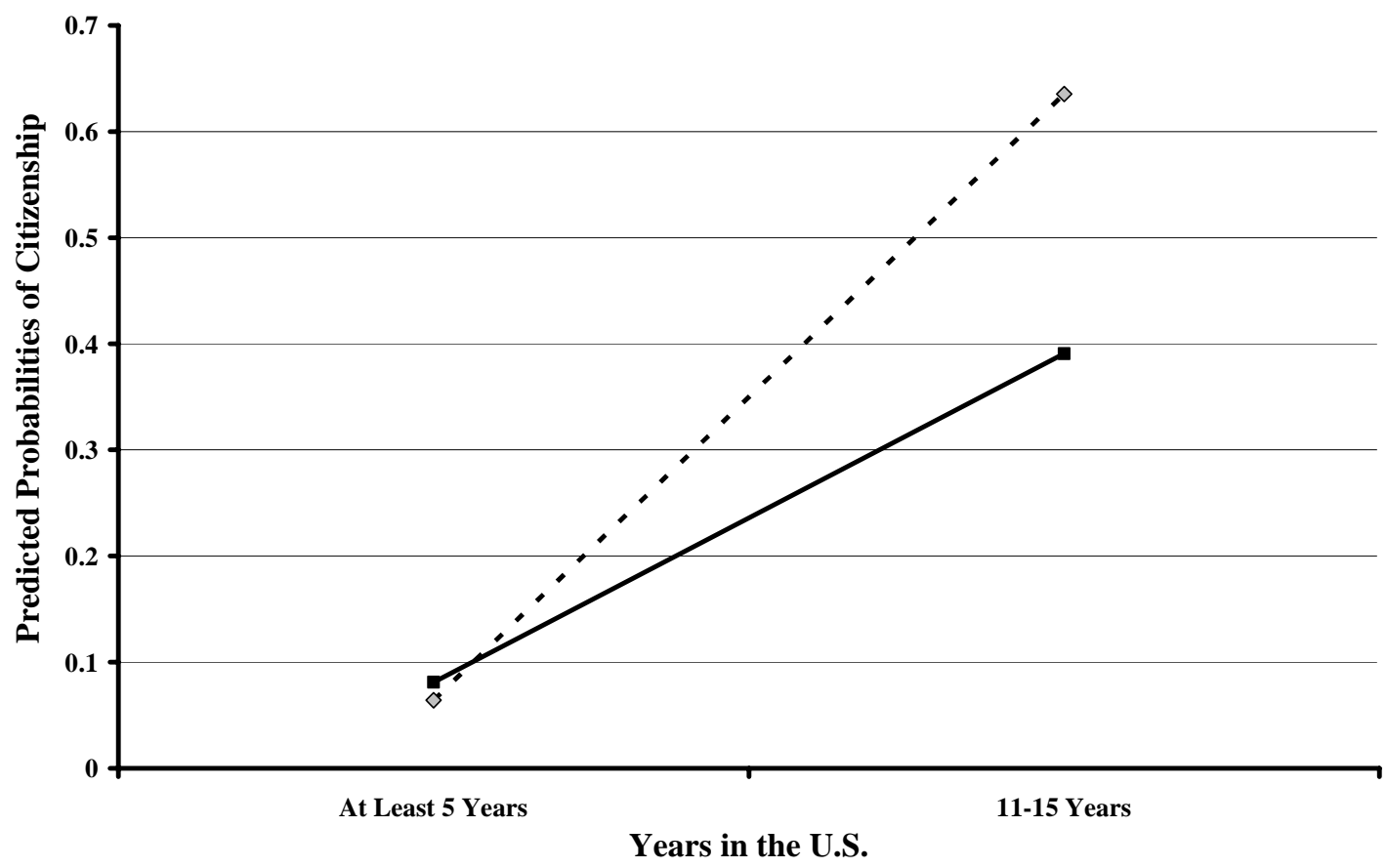

Notes: Sample selection of foreign-born individuals ages 16 to 45 for 1980 and ages 26 to 55 for 1990 .

Year of immigration 1975-1980 for 1980 and 1975-1979 for 1990 Censuses.

Source: Census Public Use Micro Samples (PUMS) 1980 and 1990, tabulations by author. 
Figure 5.-MALE SAMPLE

Smoothed Histograms of Country-Specific Growth Rates of Males: Refugee versus Economic Immigrant Sending Countries

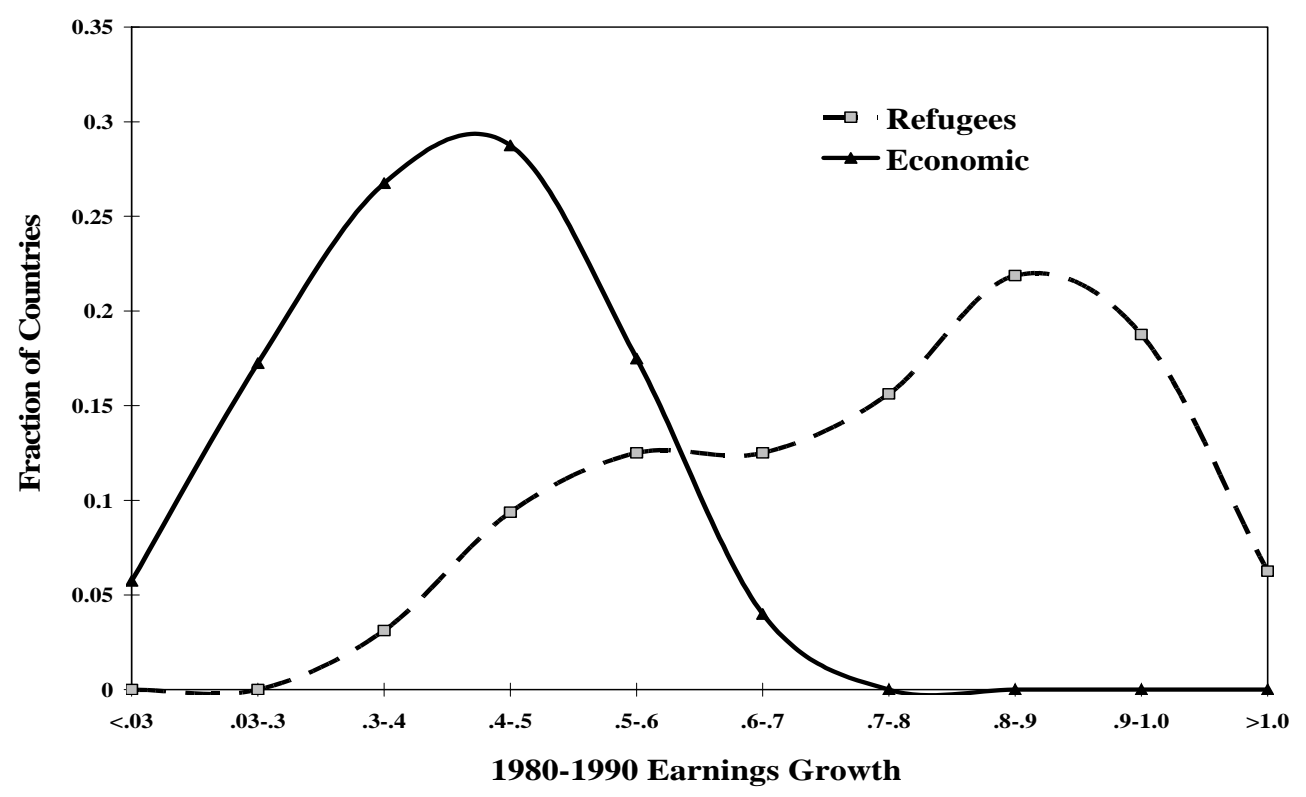

Notes: Sample selection of foreign-born individuals ages 16 to 45 for 1980 and ages 26 to 55 for 1990. Year of immigration 1975-1980 for 1980 and 1975-1979 for 1990 Censuses.

Source: Census Public Use Micro Samples (PUMS) 1980 and 1990, tabulations by author. 
FigurE 6.-FEMALE SAMPLE

Smoothed Histograms of Country-Specific Growth Rates of Females: Refugee versus Economic Immigrant Sending Countries

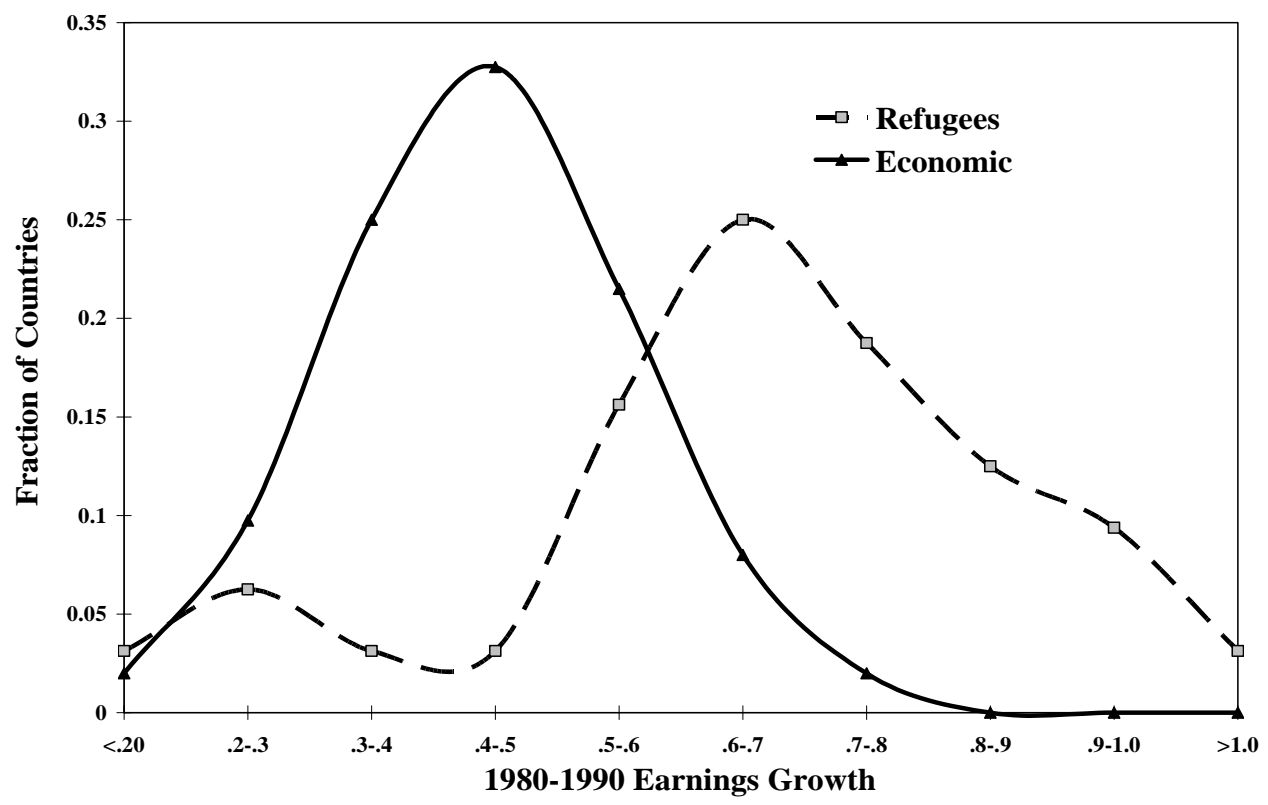

Notes: Sample selection of foreign-born individuals ages 16 to 45 for 1980 and ages 26 to 55 for 1990. Year of immigration 1975-1980 for 1980 and 1975-1979 for 1990 Censuses.

Source: Census Public Use Micro Samples (PUMS) 1980 and 1990, tabulations by author. 
TABLE 1.-SAMPLE SizeS OF REFUgEe AND ECONOMIC IMMIGRANTS FIXED COHORT YEAR OF IMMIGRATION 1975-1980*

\begin{tabular}{|c|c|c|c|}
\hline & 1980 Census & 1990 Census & Expected INS Counts $^{* *}$ \\
\hline Refugees & 12,086 & 9,614 & 12,064 \\
\hline \multicolumn{4}{|l|}{ Country of Origin } \\
\hline Afghanistan & 95 & 83 & 46 \\
\hline Cuba & 843 & 588 & 2,126 \\
\hline Soviet Union & 2,119 & 1,411 & 1,432 \\
\hline Ethiopia & 131 & 110 & 107 \\
\hline Haiti & 1,134 & 924 & 1,509 \\
\hline Cambodia & 505 & 488 & 273 \\
\hline Laos & 1,239 & 939 & 422 \\
\hline \multirow[t]{2}{*}{ Vietnam } & 6,020 & 5,071 & 6,149 \\
\hline & 1980 Census & 1990 Census & Expected INS Counts $^{* *}$ \\
\hline Economic Immigrants & 67,135 & 58,621 & 77,654 \\
\hline \multicolumn{4}{|l|}{ Country/Region of Origin } \\
\hline Mexico & 23,435 & 25,276 & 16,230 \\
\hline Central America & 4,430 & 4,797 & 3,829 \\
\hline Caribbean & 1,674 & 1,330 & 3,889 \\
\hline South America & 5,328 & 3,613 & 6,677 \\
\hline Northern Europe & 613 & 255 & 475 \\
\hline Western Europe & 1,242 & 602 & 962 \\
\hline Southern Europe & 3,607 & 2,830 & 7,460 \\
\hline Central Eastern Europe & 3,512 & 2,700 & 4,482 \\
\hline East Asia & 11,542 & 8,362 & 15,668 \\
\hline Southeast Asia & 1,558 & 891 & 1,523 \\
\hline Middle East \& Asia Minor & 4,018 & 2,289 & 5,734 \\
\hline Philippines & 5,215 & 5,101 & 9,819 \\
\hline Northern Africa & 961 & 575 & 816 \\
\hline \multicolumn{4}{|c|}{$\begin{array}{l}\text { Notes: Sample selection of foreign-born individuals ages } 16 \text { to } 45 \text { for } 1980 \text { and ages } 26 \text { to } 55 \text { for } 1990 . \text { "Year of immigration } \\
1975-1980 \text { for } 1980 \text { and } 1975-1979 \text { for } 1990 \text { Censuses, for additional information refer to footnote } 5 \text { in the paper. } \\
\text { Counts are only for the years } 1975-1979 \text { in order to make year of immigration comparable to the } 1980 \text { and } 1990 \text { Censuses. } \\
\text { However, the INS counts include all ages whereas the census counts are stratified by age. } \\
\text { Sources: Census Public Use Micro Samples (PUMS) } 1980 \text { and } 1990 .\end{array}$} \\
\hline
\end{tabular}


TABLE 2.-CHARACTERISTICS OF REFUgEES AND ECONOMIC IMMIGRANTS FOR THE FIXED COHORT YEAR OF IMMIGRATION 1975-1980* (PERCENT)

\begin{tabular}{|c|c|c|c|c|}
\hline & \multicolumn{2}{|c|}{ Refugee Immigrants } & \multicolumn{2}{|c|}{ Economic Immigrants } \\
\hline & 1980 Census & 1990 Census & 1980 Census & 1990 Census \\
\hline \multicolumn{5}{|l|}{ Gender } \\
\hline Male & 54 & 48 & 52 & 49 \\
\hline Female & 46 & 52 & 48 & 51 \\
\hline \multicolumn{5}{|l|}{ Marital Status } \\
\hline Married & 53 & 73 & 56 & 76 \\
\hline \multicolumn{5}{|l|}{ Number of Children ${ }^{a}$} \\
\hline None & 55 & 32 & 60 & 28 \\
\hline One & 17 & 18 & 16 & 16 \\
\hline Two & 13 & 24 & 13 & 27 \\
\hline Three & 6 & 13 & 6 & 16 \\
\hline Four & 4 & 7 & 2 & 7 \\
\hline Five-Nine & 5 & 6 & 2 & 5 \\
\hline \multicolumn{5}{|l|}{ Regional Enclaves } \\
\hline Northeast & 21 & 19 & 20 & 16 \\
\hline Midwest & 14 & 8 & 13 & 9 \\
\hline South & 27 & 29 & 20 & 22 \\
\hline West & 37 & 44 & 47 & 53 \\
\hline \multicolumn{5}{|l|}{ Educational Attainment } \\
\hline None, Kinder, Grade 1-4 & 9 & 9 & 12 & 15 \\
\hline Grade 5-8 & 13 & 6 & 21 & 21 \\
\hline Grade 9 & 7 & 2 & 6 & 5 \\
\hline Grade 10 & 7 & 3 & 5 & 3 \\
\hline Grade 11 & 7 & 2 & 5 & 2 \\
\hline Grade 12 & 26 & 26 & 20 & 21 \\
\hline 1-3 Years of College & 18 & 28 & 15 & 16 \\
\hline $4+$ Years of College & 13 & 24 & 16 & 17 \\
\hline \multicolumn{5}{|l|}{ Other } \\
\hline Low English & 45 & 22 & 46 & 33 \\
\hline School Enrollment & 31 & 13 & 21 & 11 \\
\hline Citizenship Status & 6 & 63 & 8 & 38 \\
\hline
\end{tabular}


TABLE 3.-DATA AND SUMMARY STATISTICS -

MEANS OF LOG ANNUAL EARNingS, LOG WEEKLy EARNINGS, AND LOG HOURLY EARNINGS

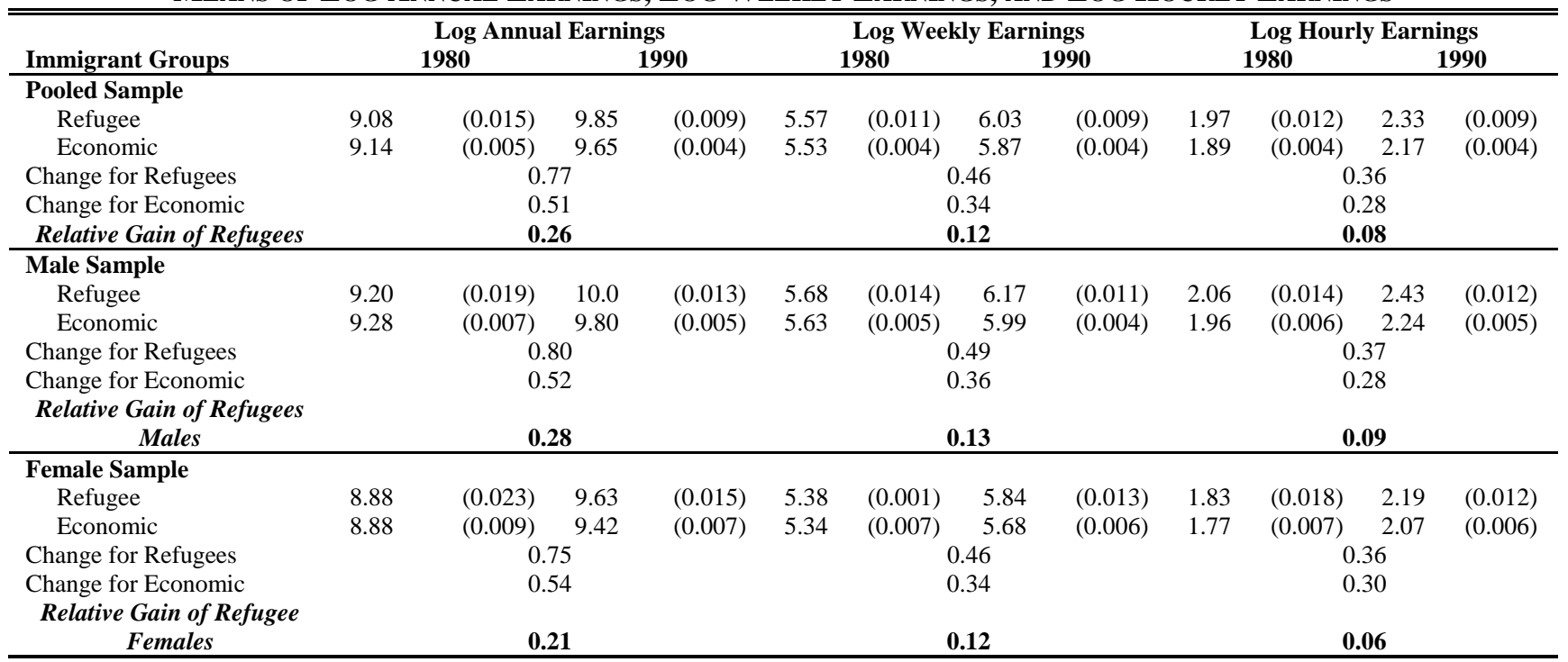

Notes: Sample selection of foreign-born individuals ages 16 to 45 for 1980 and ages 26 to 55 for 1990 . Standard deviations are in parentheses. Year of immigration 1975-1980 for 1980 and 1975-1979 for 1990 Censuses. Both annual earnings and weekly earnings are in 1989 dollars. The Census Bureau top codes annual earnings at $\$ 75,000$ in the 1980 census, I constructed an equivalent top code for annual earnings in the 1990 census by assigning an annual earnings of \$119,592 (this was calculated as \$75,000·(129/80.90), the CPI's in 1989 and 1979 were 129 and 80.90$)$ to all topcoded observations.

Sources: Census Public Use Micro Samples (PUMS) 1980 and 1990. 
TABle 4.-Log ANNUAl EARNings REgRESSiOn RESUlts FOR MALES AND FEMALES

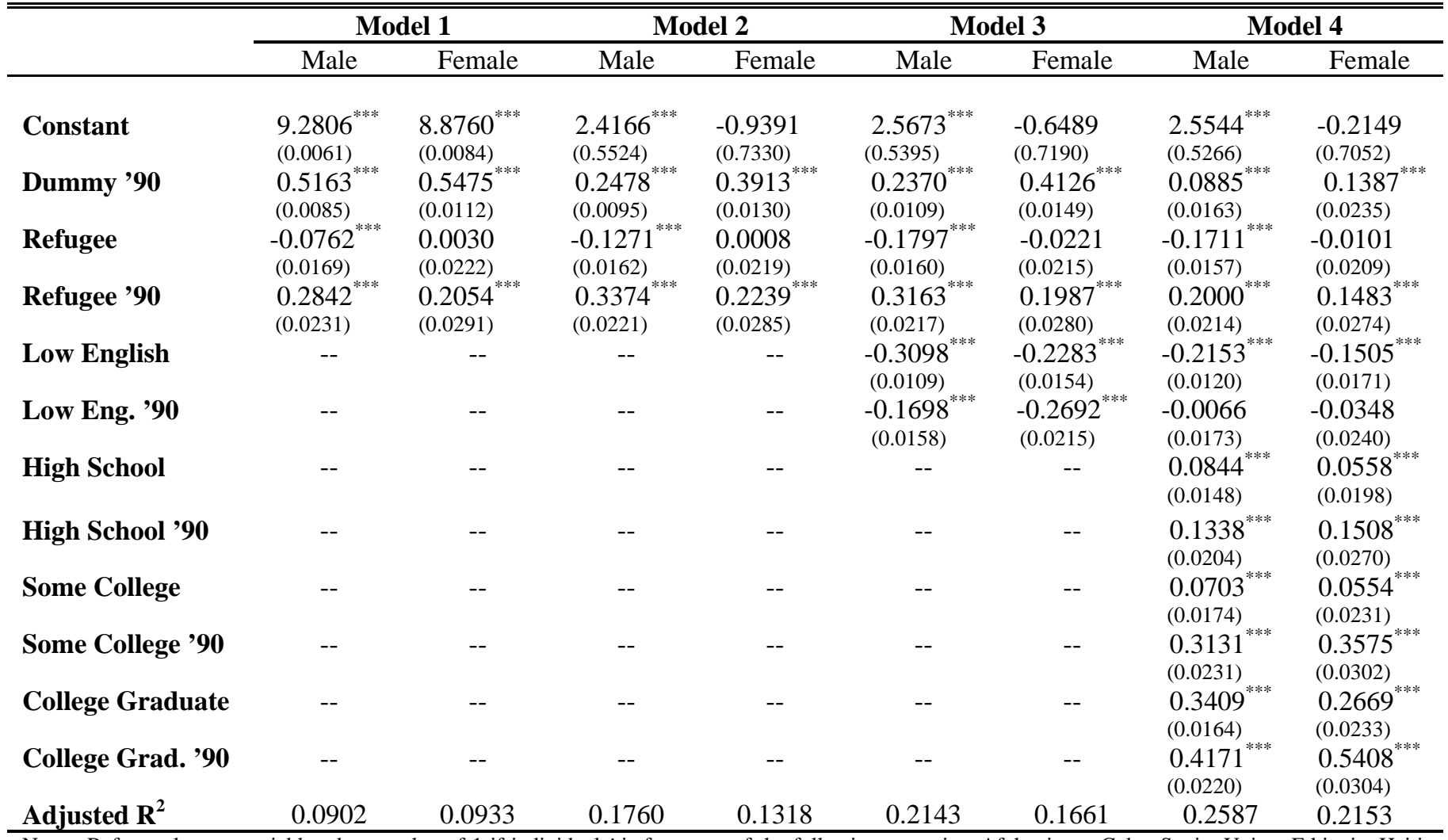

Notes: Refugee dummy variable takes a value of 1 if individual $i$ is from one of the following countries: Afghanistan, Cuba, Soviet Union, Ethiopia, Haiti, Cambodia, Laos, and Vietnam (as listed in Table 1), and 0 otherwise. The omitted comparison groups are male and female economic immigrants. Number of observations: 51,509 for male regressions and 31,724 for female regressions. ***, **, * are statistically significant at the 1, 5, 10 percent level, respectively. Sample selection of foreign-born individuals ages 16 to 45 for 1980 and ages 26 to 55 for 1990. Standard errors are in parentheses. Year of immigration 1975 1980 for 1980 and 1975-1979 for 1990 Censuses. Model Specifications:

Model 1: $\operatorname{Ln}(y)_{i, t}=\alpha_{0}+\alpha_{1} D^{1990}+\alpha_{2} D^{\text {Refugee }}+\alpha_{3} D^{1990} D^{\text {Refugee }}+\mu_{i, t}$

Model 2: $\operatorname{Ln}(y)_{i, t}=\alpha_{0}+\alpha_{1} D^{1990}+\alpha_{2} D^{\text {Refugee }}+\alpha_{3} D^{1990} D^{\text {Refugee }}+X_{i, t} \gamma+\mu_{i, t}$

Model 3: $\operatorname{Ln}(y)_{i, t}=\alpha_{0}+\alpha_{1} D^{1990}+\alpha_{2} D^{\text {Refugee }}+\alpha_{3} D^{1990} D^{\text {Refugee }}+X_{i, t} \gamma+\operatorname{LowEng}_{i, t} \beta_{t}+\mu_{i, t}$

Model 4: $\operatorname{Ln}(y)_{i, t}=\alpha_{0}+\alpha_{1} D^{1990}+\alpha_{2} D^{\text {Refugee }}+\alpha_{3} D^{1990} D^{\text {Refugee }}+X_{i, t} \gamma+\operatorname{LowEng}_{i, t} \beta_{t}+$ Educ $_{i, t} \theta_{t}+\mu_{i, t}$

where $\operatorname{Ln}(y)_{i, t}$ is $\log$ annual earnings which is defined as wages plus salary, $D^{1990}$ is a dummy variable indicating the 1990 census year, $D^{R e f u g e e}$ is a dummy variable indicating a refugee immigrant, and $D^{1990} D^{\text {Refugee }}$ is a dummy variable indicating a refugee immigrant from the 1990 census. $X_{i, t}$ is a vector of control variables (i.e., age, age ${ }^{2}$, age ${ }^{3}$, age ${ }^{4}$, region, and marital status). LowEng $g_{i, t}$ is a vector of country-specific human capital (i.e., low English ability and low English ability in 1990). Educ $c_{i, t}$ is a vector of educational attainment variables (i.e., less than high school is the omitted group, high school, some college (1 to 3 years of college), college graduate (4 plus years of college), and the interactions of these school variables with the 1990 census dummy). Lastly, $\mu_{i, t}$ is an error term.

Source: Census Public Use Micro Samples (PUMS) 1990 and 1980. 
TABle 5.-Log Hourly EARnings REgression RESUlts For MALES AND FeMALES

\begin{tabular}{|c|c|c|c|c|c|c|c|c|}
\hline & \multicolumn{2}{|c|}{ Model 1} & \multicolumn{2}{|c|}{ Model 2} & \multicolumn{2}{|c|}{ Model 3} & \multicolumn{2}{|c|}{ Model 4} \\
\hline & Male & Female & Male & Female & Male & Female & Male & Female \\
\hline Constant & $\begin{array}{l}1.9583^{* * *} \\
(0.0052)\end{array}$ & $\begin{array}{l}1.7737^{* * *} \\
(0.0067)\end{array}$ & $\begin{array}{l}2.2453^{* * *} \\
(0.4838)\end{array}$ & $\begin{array}{l}-0.5342 \\
(0.5915)\end{array}$ & $\begin{array}{l}2.4153^{* * *} \\
(0.4742)\end{array}$ & $\begin{array}{l}-0.1901 \\
(0.5789)\end{array}$ & $\begin{array}{l}2.6426^{* * *} \\
(0.4624)\end{array}$ & $\begin{array}{l}0.8897 \\
(0.5648)\end{array}$ \\
\hline Dummy90 & $\begin{array}{l}0.2829^{* * *} \\
(0.0073)\end{array}$ & $\begin{array}{l}0.2969^{* * *} \\
(0.0089)\end{array}$ & $\begin{array}{l}0.1347^{* * *} \\
(0.0083)\end{array}$ & $\begin{array}{l}0.2451^{\text {*** }} \\
(0.0105)\end{array}$ & $\begin{array}{l}0.0988^{* * *} \\
(0.0096)\end{array}$ & $\begin{array}{l}0.2376^{* * *} \\
(0.0120)\end{array}$ & $\begin{array}{l}0.0639^{* * *} \\
(0.0143)\end{array}$ & $\begin{array}{l}0.1125^{\text {*** }} \\
(0.0189)\end{array}$ \\
\hline Refugee & $\begin{array}{l}0.0975^{* * *} \\
(0.0145)\end{array}$ & $\begin{array}{l}0.0573^{* * *} \\
(0.0177)\end{array}$ & $\begin{array}{l}0.0698^{* * *} \\
(0.0142)\end{array}$ & $\begin{array}{l}0.0634^{* * *} \\
(0.0177)\end{array}$ & $\begin{array}{l}0.0205 \\
(0.0140)\end{array}$ & $\begin{array}{l}0.0319^{* *} \\
(0.0173)\end{array}$ & $\begin{array}{l}0.0214 \\
(0.0138)\end{array}$ & $\begin{array}{l}0.0452^{* * *} \\
(0.0168)\end{array}$ \\
\hline Low English & -- & -- & -- & -- & $\begin{array}{l}-0.2906^{* * *} \\
(0.0095)\end{array}$ & $\begin{array}{l}-0.2401^{* * *} \\
(0.0124)\end{array}$ & $\begin{array}{l}-0.1633^{* * *} \\
(0.0105)\end{array}$ & $\begin{array}{l}-0.1194^{* * *} \\
(0.0137)\end{array}$ \\
\hline Low Eng90 & -- & -- & -- & -- & $\begin{array}{l}-0.0639^{* * *} \\
(0.0139)\end{array}$ & $\begin{array}{l}-0.1599^{* * *} \\
(0.0173)\end{array}$ & $\begin{array}{l}0.0173 \\
(0.0152)\end{array}$ & $\begin{array}{c}-0.0288^{* * *} \\
(0.0192)\end{array}$ \\
\hline High School & -- & -- & -- & -- & -- & -- & $\begin{array}{l}0.0983^{* * *} \\
(0.0130)\end{array}$ & $\begin{array}{l}0.0952^{* * *} \\
(0.0159)\end{array}$ \\
\hline Some College '90 & -- & -- & -- & -- & -- & -- & $\begin{array}{l}0.1132^{* * *} \\
(0.0203)\end{array}$ & $\begin{array}{l}0.1234^{* * *} \\
(0.0242)\end{array}$ \\
\hline College Graduate & -- & -- & -- & -- & -- & -- & $\begin{array}{l}0.4130^{* * *} \\
(0.0144)\end{array}$ & $\begin{array}{l}0.3438^{* * *} \\
(0.0187)\end{array}$ \\
\hline College Grad. '90 & -- & -- & -- & -- & -- & -- & $\begin{array}{l}0.2167^{* * *} \\
(0.0193)\end{array}$ & $\begin{array}{l}0.3146^{* * *} \\
(0.0243)\end{array}$ \\
\hline Adjusted $\mathbf{R}^{2}$ & 0.0404 & 0.0444 & 0.0835 & 0.0624 & 0.1198 & 0.1035 & 0.1712 & 0.1653 \\
\hline
\end{tabular}

Notes: Refugee dummy variable takes a value of 1 if individual $i$ is from one of the following countries: Afghanistan, Cuba, Soviet Union, Ethiopia, Haiti, Cambodia, Laos, and Vietnam (as listed in Table 1), and 0 otherwise. The omitted comparison groups are male and female economic immigrants. Number of observations: 51,509 for male regressions and 31,724 for female regressions. ***, **, * are statistically significant at the 1 , 5, 10 percent level, respectively. Sample selection of foreign-born individuals ages 16 to 45 for 1980 and ages 26 to 55 for 1990 . Standard errors are in parentheses. Year of immigration 1975-1980 for 1980 and 1975-1979 for 1990 Censuses. Model Specifications:

Model 1: $\operatorname{Ln}(y)_{i, t}=\alpha_{0}+\alpha_{1} D^{1990}+\alpha_{2} D^{\text {Refugee }}+\alpha_{3} D^{1990} D^{\text {Refugee }}+\mu_{i, t}$

Model 2: $\operatorname{Ln}(y)_{i, t}=\alpha_{0}+\alpha_{1} D^{1990}+\alpha_{2} D^{\text {Refugee }}+\alpha_{3} D^{1990} D^{\text {Refugee }}+X_{i, t} \gamma+\mu_{i, t}$

Model 2: $\operatorname{Ln}(y)_{i, t}=\alpha_{0}+\alpha_{1} D^{1990}+\alpha_{2} D^{\text {Refugee }}+\alpha_{3} D^{1990} D^{\text {Refugee }}+X_{i, t} \gamma+\mu_{i, t}$

Model 4: $\operatorname{Ln}(y)_{i, t}=\alpha_{0}+\alpha_{1} D^{1990}+\alpha_{2} D^{\text {Refugee }}+\alpha_{3} D^{1990} D^{\text {Refugee }}+X_{i, t} \gamma+$ LowEng $_{i, t} \beta_{t}+E d u c_{i, t} \theta_{t}+\mu_{i, t}$

where $\operatorname{Ln}(y)_{i, t}$ is $\log$ hourly earnings, $D^{1990}$ is a dummy variable indicating the 1990 census year, $D^{\text {Refugee }}$ is a dummy variable indicating a refugee immigrant, and $D^{1990} D^{\text {Refugee }}$ is a dummy variable indicating a refugee immigrant from the 1990 census. $X_{i, t}$ is a vector of control variables (i.e., age, age $e^{2}$, age $e^{3}$, age ${ }^{4}$, region, and marital status). LowEng $g_{i, t}$ is a vector of country-specific human capital (i.e., low English ability and low English ability in 1990). Educi,t is a vector of educational attainment variables (i.e., less than high school is the omitted group, high school, some college (1 to 3 years of college), college graduate (4 plus years of college), and the interactions of these school variables with the 1990 census dummy). Lastly, $\mu_{i, t}$ is an error term.

Source: Census Public Use Micro Samples (PUMS) 1990 and 1980. 
TABle 6.-Log ANnual Hours Regression Results fOr MALES AND Females

\begin{tabular}{|c|c|c|c|c|c|c|c|c|}
\hline & \multicolumn{2}{|c|}{ Model 1} & \multicolumn{2}{|c|}{ Model 2} & \multicolumn{2}{|c|}{$\begin{array}{l}\text { Model } 3 \\
\end{array}$} & \multicolumn{2}{|c|}{ Model 4} \\
\hline & Male & Female & Male & Female & Male & Female & Male & Female \\
\hline Constant & $\begin{array}{l}7.3224^{* * *} \\
(0.0042)\end{array}$ & $\begin{array}{l}7.1024^{* * *} \\
(0.0064)\end{array}$ & $\begin{array}{l}0.1713 \\
(0.3881)\end{array}$ & $\begin{array}{c}-0.4049 \\
(0.5662)\end{array}$ & $\begin{array}{l}0.1520 \\
(0.3873)\end{array}$ & $\begin{array}{l}-0.4587 \\
(0.5661)\end{array}$ & $\begin{array}{c}-0.0882 \\
(0.3883)\end{array}$ & $\begin{array}{l}-1.1046^{* *} \\
(0.5710)\end{array}$ \\
\hline Dummy90 & $\begin{array}{l}0.2336^{* * *} \\
(0.0058)\end{array}$ & $\begin{array}{l}0.2506^{* * *} \\
(0.0086)\end{array}$ & $\begin{array}{l}0.1130^{* * *} \\
(0.0066)\end{array}$ & $\begin{array}{l}0.1462^{* * *} \\
(0.0100)\end{array}$ & $\begin{array}{l}0.1382^{* * *} \\
(0.0078)\end{array}$ & $\begin{array}{l}0.1750^{* * *} \\
(0.0117)\end{array}$ & $\begin{array}{l}0.0246^{* *} \\
(0.0120)\end{array}$ & $\begin{array}{l}0.0262 \\
(0.0191)\end{array}$ \\
\hline Refugee & $\begin{array}{l}-0.1737^{* * *} \\
(0.0116)\end{array}$ & $\begin{array}{l}-0.0543^{* * *} \\
(0.0170)\end{array}$ & $\begin{array}{l}-0.1969^{* * *} \\
(0.0114)\end{array}$ & $\begin{array}{l}-0.0625^{* * *} \\
(0.0169)\end{array}$ & $\begin{array}{c}-0.2001^{* * *} \\
(0.0115)\end{array}$ & $\begin{array}{l}-0.0612^{* * *} \\
(0.0169)\end{array}$ & $\begin{array}{l}-0.1925^{* * *} \\
(0.0116)\end{array}$ & $\begin{array}{l}-0.0553^{* * *} \\
(0.0170)\end{array}$ \\
\hline Refugee90 & $\begin{array}{l}0.1924^{* * *} \\
(0.0158)\end{array}$ & $\begin{array}{l}0.1390^{* * *} \\
(0.0222)\end{array}$ & $\begin{array}{l}0.2173^{* * *} \\
(0.0155)\end{array}$ & $\begin{array}{l}0.1484^{* * *} \\
(0.0220)\end{array}$ & $\begin{array}{l}0.2013^{* * *} \\
(0.0156)\end{array}$ & $\begin{array}{l}0.1377^{* * *} \\
(0.0221)\end{array}$ & $\begin{array}{l}0.1705^{* * *} \\
(0.0158)\end{array}$ & $\begin{array}{l}0.1230^{* * *} \\
(0.0222)\end{array}$ \\
\hline Low English & -- & -- & -- & -- & $\begin{array}{l}-0.0192^{* * *} \\
(0.0078)\end{array}$ & $\begin{array}{l}0.0118 \\
(0.0121)\end{array}$ & $\begin{array}{l}-0.0520^{* * *} \\
(0.0089)\end{array}$ & $\begin{array}{l}-0.0311^{* *} \\
(0.0138)\end{array}$ \\
\hline Low Eng90 & -- & -- & -- & -- & $\begin{array}{c}-0.1060^{* * *} \\
(0.0114)\end{array}$ & $\begin{array}{l}-0.1094^{* * *} \\
(0.0169)\end{array}$ & $\begin{array}{l}-0.0239^{*} \\
(0.0128)\end{array}$ & $\begin{array}{c}-0.0060 \\
(0.0194)\end{array}$ \\
\hline High School & -- & -- & -- & -- & -- & -- & $\begin{array}{l}-0.0139^{* * *} \\
(0.0109)\end{array}$ & $\begin{array}{l}-0.0394^{* * *} \\
(0.0161)\end{array}$ \\
\hline HS '90 & -- & -- & -- & -- & -- & -- & $\begin{array}{l}0.0699^{* * *} \\
(0.01150)\end{array}$ & $\begin{array}{l}0.1105^{\text {*** }} \\
(0.0219)\end{array}$ \\
\hline Some College & -- & -- & -- & -- & -- & -- & $\begin{array}{l}-0.1054^{* * *} \\
(0.0128)\end{array}$ & $\begin{array}{l}-0.1509^{* * *} \\
(0.0187)\end{array}$ \\
\hline Some College '90 & -- & -- & -- & -- & -- & -- & $\begin{array}{l}0.1999^{* * *} \\
(0.0170)\end{array}$ & $\begin{array}{l}0.2341^{* * *} \\
(0.0244)\end{array}$ \\
\hline College Graduate & -- & -- & -- & -- & -- & -- & $\begin{array}{l}-0.0721^{* * *} \\
(0.0121)\end{array}$ & $\begin{array}{l}-0.0769^{* * *} \\
(0.0189)\end{array}$ \\
\hline College Grad. '90 & -- & -- & -- & -- & -- & -- & $\begin{array}{l}0.2004^{* * *} \\
(0.0162)\end{array}$ & $\begin{array}{l}0.2262^{* * *} \\
(0.0246)\end{array}$ \\
\hline Adjusted $\mathrm{R}^{2}$ & 0.0463 & 0.0371 & 0.0907 & 0.0605 & 0.0948 & 0.0625 & 0.0988 & 0.0669 \\
\hline
\end{tabular}

Notes: Refugee dummy variable takes a value of 1 if individual $i$ is from one of the following countries: Afghanistan, Cuba, Soviet Union, Ethiopia, Haiti, Cambodia, Laos, and Vietnam (as listed in Table 1), and 0 otherwise. The omitted comparison groups are male and female economic immigrants. Number of observations: 51,509 for male regressions and 31,724 for female regressions. ***, **, * are statistically significant at the $1,5,10$ percent level, respectively. Sample selection of foreign-born individuals ages 16 to 45 for 1980 and ages 26 to 55 for 1990. Standard errors are in parentheses. Year of immigration $1975-$ 1980 for 1980 and 1975-1979 for 1990 Censuses. Model Specifications:

Model 1: $\operatorname{Ln}(y)_{i, t}=\alpha_{0}+\alpha_{1} D^{1990}+\alpha_{2} D^{\text {Refugee }}+\alpha_{3} D^{1990} D^{\text {Refugee }}+\mu_{i, t}$

Model 2: $\operatorname{Ln}(y)_{i, t}=\alpha_{0}+\alpha_{1} D^{1990}+\alpha_{2} D^{\text {Refugee }}+\alpha_{3} D^{1990} D^{\text {Refugee }}+X_{i, t} \gamma+\mu_{i, t}$

Model 3: $\operatorname{Ln}(y)_{i, t}=\alpha_{0}+\alpha_{1} D^{1990}+\alpha_{2} D^{\text {Refugee }}+\alpha_{3} D^{1990} D^{\text {Refugee }}+X_{i, t} \gamma+\operatorname{LowEng}_{i, t} \beta_{t}+\mu_{i, t}$

Model 4: $\operatorname{Ln}(y)_{i, t}=\alpha_{0}+\alpha_{1} D^{1990}+\alpha_{2} D^{\text {Refugee }}+\alpha_{3} D^{1990} D^{\text {Refugee }}+X_{i, t} \gamma+\operatorname{LowEng}_{i, t} \beta_{t}+E d u c_{i, t} \theta_{t}+\mu_{i, t}$

where $\operatorname{Ln}(y)_{i, t}$ is $\log$ annual hours, $D^{1990}$ is a dummy variable indicating the 1990 census year, $D^{\text {Refugee }}$ is a dummy variable indicating a refugee immigrant, and $D^{1990} D^{\text {Refugee }}$ is a dummy variable indicating a refugee immigrant from the 1990 census. $X_{i, t}$ is a vector of control variables (i.e., age, age ${ }^{2}$, age ${ }^{3}$, age ${ }^{4}$, region, and marital status). LowEng $g_{i, t}$ is a vector of country-specific human capital (i.e., low English ability and low English ability in 1990). Educ ${ }_{i, t}$ is a vector of educational attainment variables (i.e., less than high school is the omitted group, high school, some college (1 to 3 years of college), college graduate (4 plus years of college), and the interactions of these school variables with the 1990 census dummy). Lastly, $\mu_{i, t}$ is an error term.

Source: Census Public Use Micro Samples (PUMS) 1990 and 1980. 
TABLE 7.-1980-1990 EARNINGS GROWTH FOR COUNTRY/REgIONSPECIFIC REFUGEE AND ECONOMIC IMMIGRANTS GROUPS

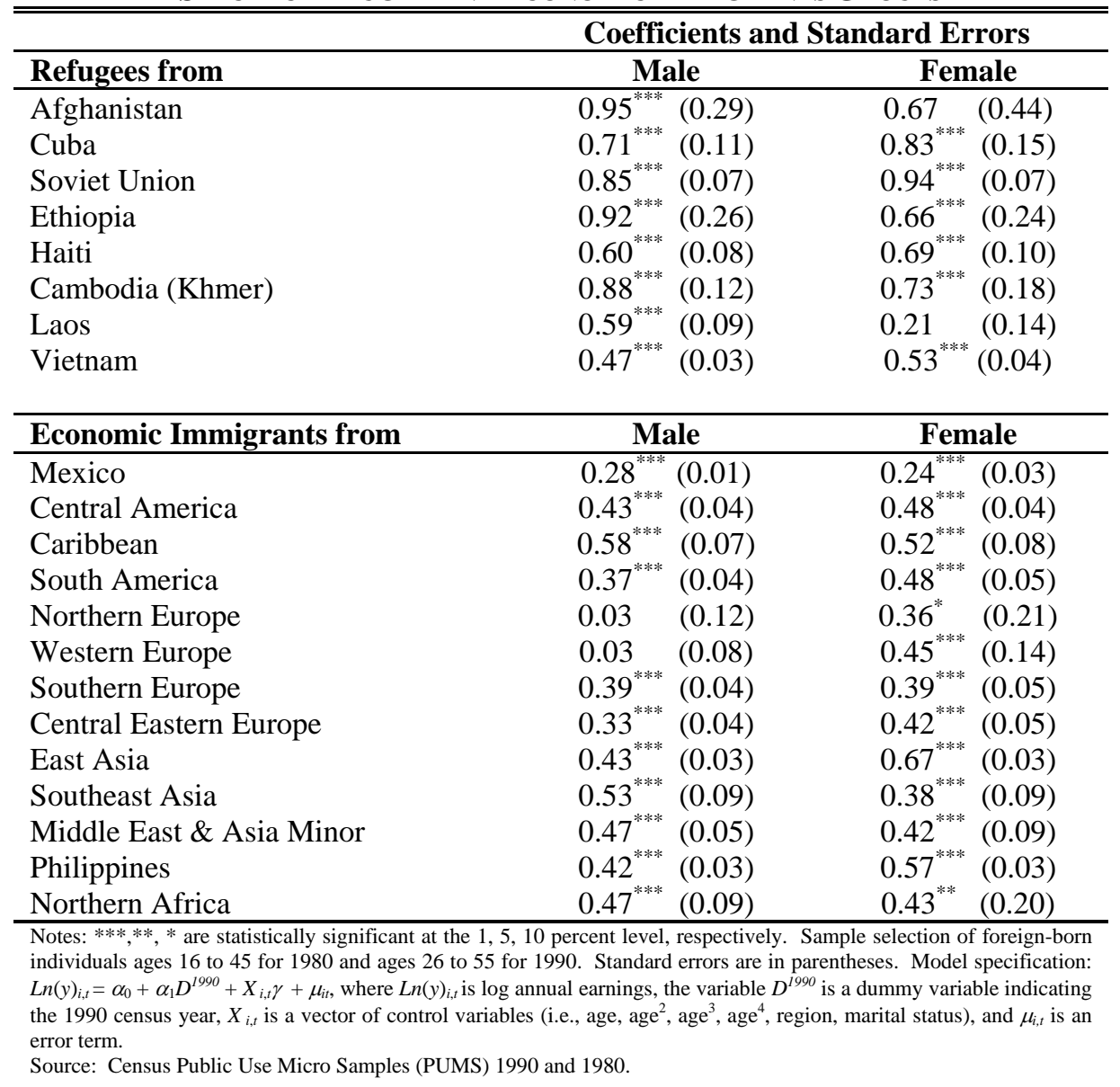


TABLE 8.-DECOMPOSITION OF EARNINGS GROWTH FROM TABLE 4

\begin{tabular}{|c|c|c|c|c|c|c|c|c|}
\hline & \multicolumn{2}{|c|}{ Model 1} & \multicolumn{2}{|c|}{ Model 2} & \multicolumn{2}{|c|}{ Model 3} & \multicolumn{2}{|c|}{ Model 4} \\
\hline & Male & Female & Male & Female & Male & Female & Male & Female \\
\hline $\begin{array}{l}\text { Earnings growth of } \\
\text { refugees relative to } \\
\text { economic } \\
\text { immigrants from } \\
1980 \text { to } 1990, \alpha_{3}\end{array}$ & 0.28 & 0.21 & 0.34 & 0.22 & 0.32 & 0.20 & 0.20 & 0.15 \\
\hline $\begin{array}{l}\text { Asian Refugee term, } \\
\qquad \boldsymbol{s}_{\boldsymbol{R}} \boldsymbol{\alpha}_{3}{ }^{\boldsymbol{A}}\end{array}$ & 0.03 & -0.02 & 0.01 & -0.05 & 0.01 & -0.04 & 0.01 & -0.02 \\
\hline $\begin{array}{l}\text { Non-Asian Refugee } \\
\text { term, }\left(\mathbf{1}-\boldsymbol{s}_{\boldsymbol{R}}\right) \boldsymbol{\alpha}_{3}{ }^{N}\end{array}$ & 0.23 & 0.27 & 0.31 & 0.33 & 0.29 & 0.29 & 0.22 & 0.22 \\
\hline $\begin{array}{l}\text { Asian effect term, } \\
\left(\boldsymbol{y}^{A, E}-\boldsymbol{y}^{N A, E}\right)\left(\boldsymbol{s}_{R}-s_{E}\right)\end{array}$ & 0.02 & -0.04 & 0.02 & -0.06 & 0.02 & -0.05 & -0.03 & -0.05 \\
\hline
\end{tabular}


TABLE 9.-MEANS OF LOW ENGLish

\begin{tabular}{|c|c|c|c|c|}
\hline \multirow{3}{*}{$\begin{array}{l}\text { Immigrant Groups } \\
\text { Pooled }\end{array}$} & \multicolumn{4}{|c|}{ Low English } \\
\hline & \multicolumn{2}{|c|}{1980} & \multicolumn{2}{|c|}{1990} \\
\hline & & & & \\
\hline Refugee & 0.45 & $(0.005)$ & 0.22 & $(0.004)$ \\
\hline Economic & 0.46 & $(0.002)$ & 0.33 & $(0.002)$ \\
\hline Change for Refugees & \multicolumn{4}{|c|}{-0.23} \\
\hline Change for Economic & \multicolumn{4}{|c|}{-0.13} \\
\hline Relative Gain of Refugees & \multicolumn{4}{|c|}{0.10} \\
\hline \multicolumn{5}{|l|}{ Male } \\
\hline Refugee & 0.43 & $(0.006)$ & 0.19 & $(0.006)$ \\
\hline Economic & 0.46 & $(0.003)$ & 0.31 & $(0.003)$ \\
\hline Change for Refugees & \multicolumn{4}{|c|}{-0.24} \\
\hline Change for Economic & \multicolumn{4}{|c|}{-0.15} \\
\hline Relative Gain of Refugees Males & \multicolumn{4}{|c|}{0.09} \\
\hline \multicolumn{5}{|l|}{ Female } \\
\hline Refugee & 0.48 & $(0.007)$ & 0.26 & $(0.006)$ \\
\hline Economic & 0.47 & $(0.003)$ & 0.35 & $(0.003)$ \\
\hline Change for Refugees & \multicolumn{4}{|c|}{-0.22} \\
\hline Change for Economic & \multicolumn{4}{|c|}{-0.12} \\
\hline Relative Gain of Refugee Females & \multicolumn{4}{|c|}{$\mathbf{0 . 1 0}$} \\
\hline
\end{tabular}

Table 10.-Percent Contribution To Annual Earnings, AVerage hourly earnings, ANd Annual HOURS GROWTH ATTRIBUTABLE TO ENGLISH IMPROVEMENT

\begin{tabular}{lcccc}
\hline \hline & \multicolumn{2}{c}{ Refugee Immigrants } & \multicolumn{2}{c}{ Economic Immigrants } \\
& Males & Females & Males & Females \\
\hline Annual Earnings & 7 & 5 & 6 & 4 \\
Average Hourly Earnings & 4 & 4 & 4 & 3 \\
Annual Hours & 3 & 1 & 2 & 1 \\
\hline Notes: Sample selection of foreign-born individuals ages 16 to 45 for 1980 and ages 26 to 55 for 1990. Year of immigration 1975-1980 for 1980 and 1975-1979 for \\
1990 Censuses. \\
Source: Census Public Use Micro Samples (PUMS) 1990 and 1980.
\end{tabular}




\section{APPENDICES}

\section{APPEndiX A.1}

Equation (8) in the paper is derived as follows: Let $y^{R}$ and $y^{E}$ represent mean outcomes for these two groups,

$$
y^{R}=s_{R} y^{A, R}+\left(1-s_{R}\right) y^{N A, R}(1) \text { and } y^{E}=s_{E} y^{A, E}+\left(1-s_{E}\right) y^{N A, E}
$$

Subtracting equation (2) from equation (1), and then adding and subtracting the terms $s_{R} y^{N A, E}$ and $s_{R} y^{A, E}$, we have

$y^{R}-y^{E}=\left[s_{R} y^{A, R}+\left(1-s_{R}\right) y^{N A, R}\right]-\left[s_{E} y^{A, E}+\left(1-s_{E}\right) y^{N A, E}\right]+\left(s_{R} y^{N A, E}-s_{R} y^{N A, E}\right)+\left(s_{R} y^{A, E}-s_{R} y^{A, E}\right)$

Expanding and collecting terms from equation (3) we get our algebraic expression:

$$
y^{R}-y^{E}=s_{R}\left(y^{A, R}-y^{A, E}\right)+\left(1-s_{R}\right)\left(y^{N A, R}-y^{N A, E}\right)+\left(y^{A, E}-y^{N A, E}\right)\left(s_{R}-s_{E}\right)
$$

\section{APPEndiX A.2}

The coefficients $\alpha_{3}{ }^{A}$ and $\alpha_{3}{ }^{N}$ are obtained from the following regression estimation:

Ln(annearn $)_{i, t}=\alpha_{0}+\alpha_{0}^{A} D^{A}+X_{i, t} \gamma+\alpha_{1}^{A} D^{1990} D^{A}+\alpha_{1}{ }^{N} D^{1990} D^{N}+\alpha_{2}^{A} D^{R e f} D^{A}+\alpha_{2}{ }^{N} D^{R e f} D^{N}+$ $\alpha_{3}{ }^{A} D^{1990} D^{R e f} D^{A}+\alpha_{3}{ }^{N} D^{1990} D^{R e f} D^{N}+\mu_{i t}$,

where the dependent variable is once again log annual earnings. The explanatory variables are: a vector of control variables, $X_{i, t}$ (i.e., age, age ${ }^{2}$, age ${ }^{3}$ age $^{4}$, region, marital status, low English, low English in 1990, and educational attainment), $D^{A}$ is a dummy variable for any Asian immigrant, $D^{1990} D^{A}$ is a dummy variable for any Asian immigrant in $1990, D^{1990} D^{N}$ is a dummy variable for any non-Asian immigrant in $1990, D^{R e f} D^{A}$ is a dummy variable indicating Asian refugee, $D^{R e f} D^{N}$ is a dummy variable indicating non-Asian refugee, $D^{1990} D^{R e f} D^{A}$ is a dummy variable indicating Asian refugee in $1990, D^{1990} D^{R e f} D^{N}$ is a dummy variable indicating non-Asian refugee in 1990 , and $\mu_{i t}$ is an error term. For the interested reader, Table A.1 reports the full set of estimated coefficients from this regression. Generally, we observe the same results as reported in Table 8.

$S_{R}$ is calculated from the raw data, and the coefficients $\alpha_{3}, \alpha_{3}{ }^{A}$, and $\alpha_{3}{ }^{N}$ are given by the regressions results. Having calculated $\alpha_{3}, \alpha_{3}{ }^{A}, \alpha_{3}{ }^{N}$, and $s_{R}$, the corresponding Asian effect term is easily obtained. 
TABLE A1.-REgRESSION RESULTS USED IN TABLE 8

\begin{tabular}{|c|c|c|c|c|}
\hline \multicolumn{5}{|c|}{ Dependent Variable Log Annual Earnings } \\
\hline Male Sample & Model 1 & Model 2 & Model 3 & Model 4 \\
\hline Asian Constant & $9.4530^{* * *}(0.0128)$ & $2.3342^{* * *}(0.5477)$ & $2.4860^{* * *}(0.5370)$ & $2.5526^{* * *}(0.5260)$ \\
\hline Non-Asian Constant & $9.2299^{* * *}(0.0069)$ & $2.2568^{* * *}(0.5477)$ & $2.5052^{* * *}(0.5370)$ & $2.6694^{* * *}(0.5263)$ \\
\hline Asian90 & $0.6982^{* * *}(0.0182)$ & $0.5184^{* * *}(0.0179)$ & $0.4773^{* * *}(0.0178)$ & $0.2168^{* * *}(0.0250)$ \\
\hline Non-Asian90 & $0.4761^{* * *}(0.0095)$ & $0.1969^{* * *}(0.0105)$ & $0.1637^{* * *}(0.0124)$ & $0.0716^{* * *}(0.0164)$ \\
\hline Asian Refugee & $-0.2225^{* * *}(0.0234)$ & $-0.1063^{* * *}(0.0224)$ & $-0.0904^{* * *}(0.0220)$ & $0.0001 \quad(0.0218)$ \\
\hline Non-Asian Ref & $-0.0715^{* * *}(0.0269)$ & $-0.2525^{* * *}(0.0259)$ & $-0.3190^{* * *}(0.0255)$ & $-0.3585^{* * *}(0.0250)$ \\
\hline Asian Refugee 90 & $0.0799^{* * *}(0.0319)$ & $0.0254 \quad(0.0304)$ & $0.0279 \quad(0.0299)$ & $0.0320 \quad(0.0296)$ \\
\hline Non-Asian Ref 90 & $0.3631^{* * *}(0.0378)$ & $0.4932^{* * *}(0.0363)$ & $0.4680^{* * *}(0.0357)$ & $0.3443^{* * *}(0.0352)$ \\
\hline & 0.1105 & 0.1900 & 0.2217 & 0.2606 \\
\hline \multicolumn{5}{|c|}{ Dependent Variable Log Annual Earnings } \\
\hline Female Sample & Model 1 & Model 2 & Model 3 & Model 4 \\
\hline Asian Constant & $8.9908^{* * *}(0.0134)$ & $-1.5365^{* *}(0.7236)$ & $-1.2657^{*}(0.7143)$ & $(0.7040)$ \\
\hline Non-Asian Constant & $8.8054^{* * *}(0.0103)$ & $-1.6361^{* *}(0.7225)$ & $-1.2912^{*}(0.7133)$ & $(0.7036)$ \\
\hline Asian90 & $0.7307^{* * *}(0.0180)$ & $0.6516^{* * *}(0.0190)$ & $0.6251^{* * *}(0.0192)$ & $0.3084^{* * *}(0.0294)$ \\
\hline Non-Asian90 & $0.4481^{* * *}(0.0137)$ & $0.2810^{* * *}(0.0155)$ & $0.2867^{* * *}(0.0185)$ & $0.1054^{* * *}(0.0244)$ \\
\hline Asian Refugee & $(0.0292)$ & $0.0594^{* *}(0.0288)$ & $0.0799^{* * *}(0.0284)$ & $0.1475^{* * *}(0.0283)$ \\
\hline Non-Asian Ref & $(0.0464)$ & $-0.1461^{* * *}(0.0335)$ & $-0.1916^{* * *}(0.0332)$ & $-0.2333^{* * *}(0.0327)$ \\
\hline Asian Refugee 90 & $-0.0643^{*}(0.0379)$ & $-0.1280^{* * *}(0.0372)$ & $-0.1073^{* * *}(0.0368)$ & $-0.0603^{*}(0.0365)$ \\
\hline Non-Asian Ref 90 & $0.4403^{* * *}(0.0553)$ & $0.5279^{* * *}(0.0446)$ & $0.4732^{* * *}(0.0443)$ & $0.3488^{* * *}(0.0438)$ \\
\hline Adjusted $R^{2}$ & 0.2339 & 0.1603 & 0.1832 & 0.2203 \\
\hline \multicolumn{5}{|c|}{$\begin{array}{l}\text { Notes: Number of observations for the male and female regressions: } 51,509 \text { and } 31,724 . * * *, * *, * \text { are statistically significant at the } 1,5,10 \\
\text { percent level, respectively. Model specification: } \\
L n(\text { annearn })_{i, t}=\alpha_{0}+\alpha_{0}^{A} D^{A}+X_{i, t} \gamma_{t}+\alpha_{1}^{A} D^{1990} D^{A}+\alpha_{1}^{N} D^{1990} D^{N}+\alpha_{2}^{A} D^{R e f} D^{A}+\alpha_{2}{ }^{N} D^{R e f} D^{N}+\alpha_{3}^{A} D^{1990} D^{R e f} D^{A}+\alpha_{3}^{N} D^{1990} D^{R e f} D^{N}+\mu_{i t,} \\
\text { where } L n(\text { annearn })_{i, t} \text { is log annual earnings, which is defined as wages plus salary. The explanatory variables are: a vector of control variables, } \\
X_{i, t} \text { (i.e., age, age }{ }^{2} \text {, age, age }{ }^{3} \text {, region, marital status, low English, low English in } 1990 \text {, educational attainment, and educational attainment in } \\
1990), D^{A} \text { is a dummy variable for any Asian immigrant, } D^{1990} D^{A} \text { is a dummy variable for any Asian immigrant in } 1990, D^{1990} D^{N} \text { is a dummy } \\
\text { variable for any non-Asian immigrant in } 1990, D^{R e f} D^{A} \text { is a dummy variable indicating Asian refugee, } D^{R e f} D^{N} \text { is a dummy variable indicating non- } \\
\text { Asian refugee, } D^{1990} D^{R e f} D^{A} \text { is a dummy variable indicating Asian refugee in } 1990, D^{1990} D^{R e f} D^{N} \text { is a dummy variable indicating non-Asian refugee } \\
\text { in } 1990 \text {, and } \mu_{i, t} \text { is an error term. } \\
\text { Source: Census Public Use Micro Samples (PUMS) } 1990 \text { and } 1980 \text {. }\end{array}$} \\
\hline
\end{tabular}

